\title{
Major perturbations in the global carbon cycle and photosymbiont-bearing planktic foraminifera during the early Eocene
}

\author{
Valeria Luciani ${ }^{1}$, Gerald R. Dickens ${ }^{2,3}$, Jan Backman ${ }^{2}$, Eliana Fornaciari ${ }^{4}$, Luca Giusberti ${ }^{4}$, Claudia Agnini ${ }^{4}$, and \\ Roberta D'Onofrio ${ }^{1}$ \\ ${ }^{1}$ Department of Physics and Earth Sciences, Ferrara University, Polo Scientifico Tecnologico, Via G. Saragat 1, \\ 44100 Ferrara, Italy \\ ${ }^{2}$ Department of Geological Sciences, Stockholm University, 10691 Stockholm, Sweden \\ ${ }^{3}$ Department of Earth Science, Rice University, Houston, TX 77005, USA \\ ${ }^{4}$ Department of Geosciences, Padova University, Via G. Gradenigo 6, 35131 Padova, Italy
}

Correspondence to: Valeria Luciani (valeria.luciani@unife.it)

Received: 10 February 2015 - Published in Clim. Past Discuss.: 16 March 2015

Revised: 23 March 2016 - Accepted: 24 March 2016 - Published: 15 April 2016

\begin{abstract}
A marked switch in the abundance of the planktic foraminiferal genera Morozovella and Acarinina occurred at low-latitude sites near the start of the Early Eocene Climatic Optimum (EECO), a multi-million-year interval when Earth surface temperatures reached their Cenozoic maximum. Stable carbon and oxygen isotope data of bulk sediment are presented from across the EECO at two locations: Possagno in northeast Italy and Deep Sea Drilling Project (DSDP) Site 577 in the northwest Pacific. Relative abundances of planktic foraminifera are presented from these two locations, as well as from Ocean Drilling Program (ODP) Site 1051 in the northwest Atlantic. All three sections have good stratigraphic markers, and the $\delta^{13} \mathrm{C}$ records at each section can be correlated amongst each other and to $\delta^{13} \mathrm{C}$ records at other locations across the globe. These records show that a series of negative carbon isotope excursions (CIEs) occurred before, during and across the EECO, which is defined here as the interval between the J event and the base of Discoaster sublodoensis. Significant though ephemeral modifications in planktic foraminiferal assemblages coincide with some of the short-term CIEs, which were marked by increases in the relative abundance of Acarinina, similar to what happened across established hyperthermal events in Tethyan settings prior to the EECO. Most crucially, a temporal link exists between the onset of the EECO, carbon cycle changes during this time and the decline in Morozovella. Possible causes are mani-
\end{abstract}

fold and may include temperature effects on photosymbiontbearing planktic foraminifera and changes in ocean chemistry.

\section{Introduction}

Cenozoic Earth surface temperatures attained their warmest long-term state during the Early Eocene Climatic Optimum (EECO). This was a 2-4 Myr time interval (discussed below) centered at ca. $51 \mathrm{Ma}$ (Fig. 1), when average high-latitude temperatures exceeded those in the present day by at least $10^{\circ} \mathrm{C}$ (Zachos et al., 2008; Bijl et al., 2009; Huber and Caballero, 2011; Hollis et al., 2012; Pross et al., 2012; Inglis et al., 2015). Several short-term (<200 kyr) global warming events (Fig. 1) occurred before the EECO. The PaleoceneEocene Thermal Maximum (PETM) provides the archetypical example: about 55.9 Ma (Vandenberghe et al., 2012; Hilgen et al., 2015) temperatures soared an additional 5$6^{\circ} \mathrm{C}$ relative to background conditions (Sluijs et al., 2006, 2007; Dunkley Jones et al., 2013). Evidence exists for at least two other significant Eocene warming events (Cramer et al., 2003; Lourens et al., 2005; Röhl et al., 2005; Thomas et al., 2006; Nicolo et al., 2007; Agnini et al., 2009; Coccioni et al., 2012; Lauretano et al., 2015; Westerhold et al., 2015): one ca. 54.1 Ma and named H-1 or Eocene Thermal Maximum 2 (ETM-2, also referred to as the Elmo event) and one 


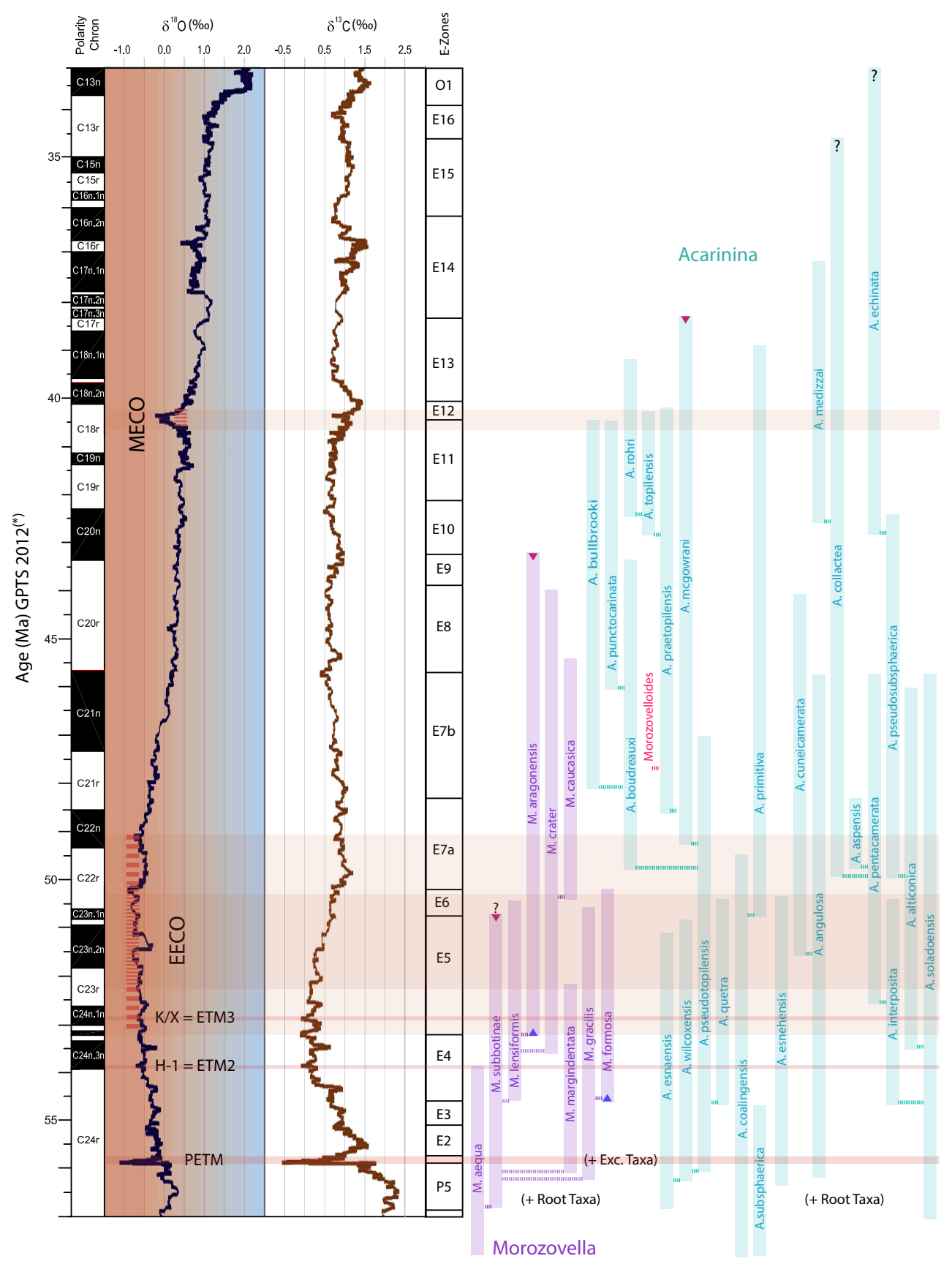

Figure 1. Evolution of climate, carbon cycling and planktic foraminifera across the middle Paleogene on the Geomagnetic Polarity Time Scale (GPTS) 2012 timescale. The left side shows polarity chrons and smoothed oxygen and carbon isotope records of benthic foraminifera, slightly modified from Vandenberghe et al. (2012). Oxygen and carbon isotope values come from compilations by Zachos et al. (2008) and Cramer et al. (2009). The middle of the figure indicates planktic foraminiferal biozones by Wade et al. (2011) with three modifications. The lower boundary for Zone E7a is now based on the first occurrence of Astrorotalia palmerae due to diachroneity in the first appearance of the previously selected marker Acarinina cuneicamerata (Luciani and Giusberti, 2014). The base of Zone E5, identified by the first appearance of Morozovella aragonensis, occurs in the middle of C24n instead of lower C23r (see text). A question marks the top of Morozovella subbotinae because there is diachroneity for this occurrence (see text). Right side shows a partial view of Morozovella and Acarinina evolution as envisioned by Pearson et al. (2006) and Aze et al. (2011). It does not include several "root taxa" that disappear in the earliest Eocene (e.g., $M$. velascoensis) or "excursion taxa" that appear during the Paleocene-Eocene Thermal Maximum (PETM) (e.g., M. allisonensis). Superimposed on these records are key intervals of climate change, including the Early Eocene Climatic Optimum (EECO), the Middle Eocene Climatic Optimum (MECO) and the three well-documented early Eocene hyperthermal events. The extent of the EECO is not precise because of stratigraphic issues (see text). Red and blue triangles: top and base of the Morozovella and Acarinina zonal markers. 
at $52.8 \mathrm{Ma}$ and variously named $\mathrm{K}, \mathrm{X}$ or ETM-3 (hereafter called $\mathrm{K} / \mathrm{X}$ ). However, additional brief warming events may have spanned the early Eocene (Cramer et al., 2003; Lourens et al., 2005; Röhl et al., 2005; Thomas et al., 2006; Nicolo et al., 2007; Agnini et al., 2009; Coccioni et al., 2012; Lauretano et al., 2015; Westerhold et al.,2015; Kirtland-Turner et al., 2014), and the EECO may comprise a series of successive events (Slotnick et al., 2012). Both long-term and shortterm intervals of warming corresponded to major changes in global carbon cycling, although the precise timing between these parameters remains insufficiently resolved.

In benthic foraminiferal stable-isotope records for the early Paleogene (Fig. 1), $\delta^{18} \mathrm{O}$ serves as a proxy for deepwater temperature, while $\delta^{13} \mathrm{C}$ relates to the composition of deep-water dissolved inorganic carbon (DIC). The highest $\delta^{13} \mathrm{C}$ values of the Cenozoic occurred at ca. $58 \mathrm{Ma}$. From this Paleocene Carbon Isotope Maximum (PCIM), benthic foraminiferal $\delta^{13} \mathrm{C}$ values plunge by approximately $2.5 \%$ o to reach a near-Cenozoic minimum at or near the start of the EECO and subsequently rise by approximately $1.5 \%$ o across this interval (Shackleton and Hall, 1984; Shackleton, 1986; Zachos et al., 2001, 2008; Cramer et al., 2009). Benthic foraminiferal $\delta^{13} \mathrm{C}$ records also exhibit prominent negative carbon isotope excursions (CIEs) across the three hyperthermals mentioned above (Kennett and Stott, 1991; Littler et al., 2014; Lauretano et al., 2015). Crucially, at least from the late Paleocene to the start of the EECO, similar $\delta^{13} \mathrm{C}$ records occur in other carbon-bearing phases, such as bulk marine carbonate, planktic foraminifera, and various marine and terrestrial organic carbon compounds (Shackleton, 1986; Schmitz et al., 1996; Lourens et al., 2005; Nicolo et al., 2007; Agnini et al., 2009, 2016; Leon-Rodriguez and Dickens, 2010; Abels et al., 2012; Coccioni et al., 2012; Sluijs and Dickens, 2012; Slotnick et al., 2012, 2015a; Clyde et al., 2013). This strongly suggests that observed changes in $\delta^{13} \mathrm{C}$, both long-term trends as well as short-term perturbations, represent variations in the input and output of ${ }^{13} \mathrm{C}$ depleted carbon to the exogenic carbon cycle (Shackleton, 1986; Dickens et al., 1995; Dickens, 2000; Kurtz et al., 2003; Komar et al., 2013).

Significant biotic changes occur in terrestrial and marine environments during times when the early Paleogene $\delta^{18} \mathrm{O}$ and $\delta^{13} \mathrm{C}$ records show major variations. This has been recognized for the PETM, where land sections exhibit a prominent mammal turnover (Gingerich 2001, 2003; McInerney and Wing, 2011; Clyde et al., 2013) and where marine sections reveal a profound benthic foraminiferal extinction (Thomas, 1998), turnovers in calcareous nannoplankton, ostracods, corals and larger benthic foraminifera (Raffi and De Bernardi, 2008; Scheibner and Speijer, 2008; Yamaguchi and Norris, 2012; Agnini et al., 2014), and the appearance of excursion taxa in calcareous nannoplankton, dinoflagellates and planktic foraminifera (Kelly et al., 1996, 1998; Crouch et al., 2001; Sluijs et al., 2006; Self-Trail et al., 2012). Major plant and mammal turnovers also occurred on land during the longer EECO (Wing et al., 1991; Zonneveld et al., 2000; Wilf et al., 2003; Falkowski et al., 2005; Woodburne et al., 2009; Figueirido et al., 2012). In the marine realm, evolutionary trends across the EECO have been noted, in particular the inception of modern calcareous nannofossil community structure (Agnini et al., 2006, 2014; Schneider et al., 2011; Shamrock et al., 2012) and possibly of diatoms (Sims et al., 2006; Oreshkina, 2012). These observations, both from continents and the oceans, support an overarching hypothesis that climate change drives biotic evolution, at least in part (Ezard et al., 2011).

Planktic foraminiferal assemblages are abundant in carbonate-bearing marine sediments and display distinct evolutionary trends that can often be correlated to climate variability (Schmidt et al., 2004; Ezard et al., 2011; Fraass et al., 2015). This is especially true in the early Paleogene, even though the relationship between climate variability and planktic foraminiferal evolution remains insufficiently known. At the beginning of the Eocene, planktic foraminifera had evolved over ca. $10 \mathrm{Myr}$ following the Cretaceous-Paleogene mass extinction event. Several early Paleogene phylogenetic lines evolved, occupying different ecological niches in the upper water column. Subsequently, a major diversification occurred during the early Eocene, which resulted in a peak of planktic foraminiferal diversity during the middle Eocene (Norris, 1991; Schmidt et al., 2004; Pearson et al., 2006; Aze et al., 2011; Ezard et al., 2011; Fraass et al., 2015).

In this study, we focus on the evolution of two planktic foraminiferal genera: Morozovella and Acarinina (Fig. 1). These two genera belong to the "muricate group", a term derived from the muricae that form layered pustules on the test wall. These two genera are of particular interest because of their dominance among tropical and subtropical assemblages of the early Paleogene oceans and because these genera show a major turnover in taxonomic diversity close to the beginning of the EECO, one that comprises species reduction among Morozovella and species diversification among Acarinina (Lu and Keller, 1995; Lu et al., 1998; Pearson et al., 2006; Aze et al., 2011).

Numerous lower Eocene sedimentary sections from lower latitudes contain well-recognizable (albeit often recrystallized) planktic foraminiferal tests. Changes in foraminiferal assemblages presumably reflect relationships between climate and carbon cycling across the EECO. The present problem is that no section examined to date provides counts of foraminiferal assemblages, detailed stable-isotope records and robust planktic foraminiferal biostratigraphies across the entire EECO. Indeed, at present, only a few sites have detailed and interpretable stable-isotope records across much of the EECO (Slotnick et al., 2012, 2015a; Kirtland-Turner et al., 2014). Furthermore, the EECO lacks formal definition. As a consequence, any relationship between climatic perturbations during the EECO and the evolution of planktic foraminifera remains speculative. Here, we add new data 


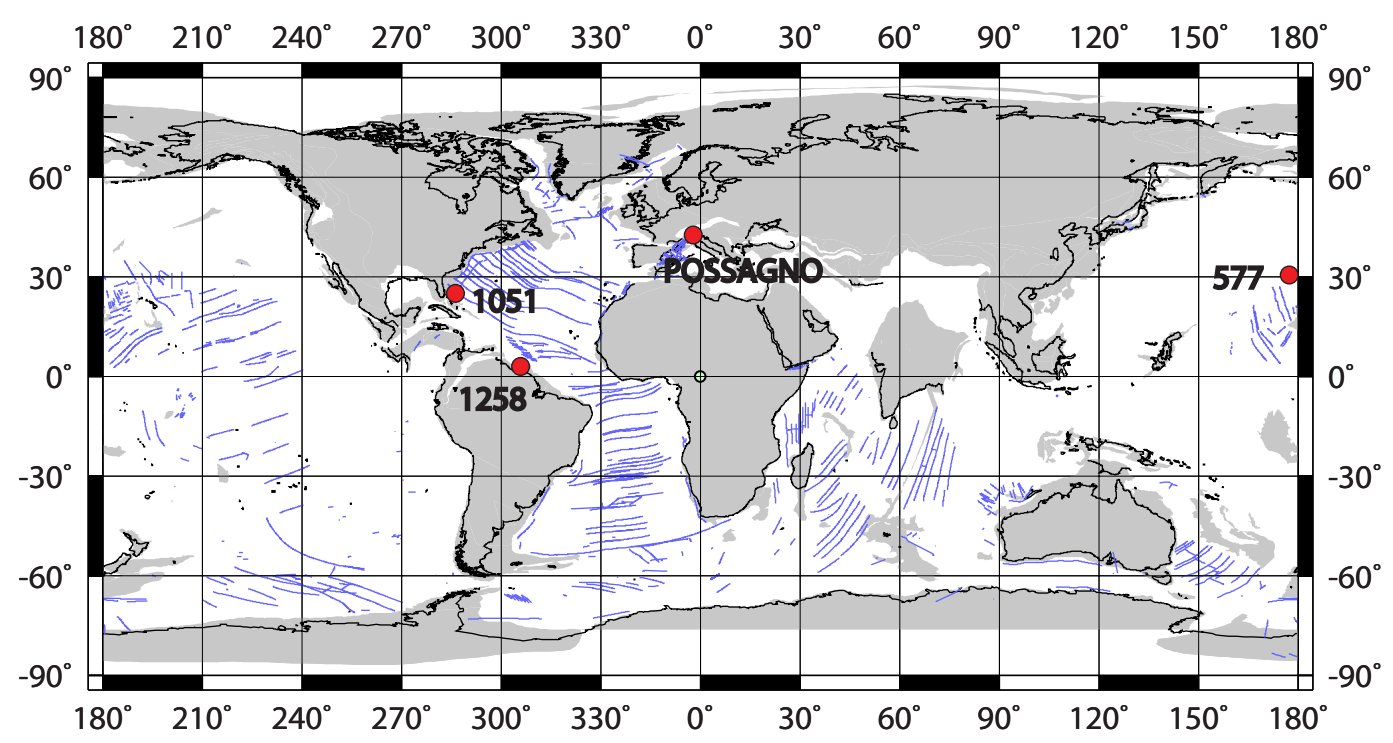

$50 \mathrm{Ma}$ Reconstruction

Figure 2. Approximate locations of the three sites discussed in this work during the early Eocene. Also shown is Site 1258 , which has a bulk carbonate $\delta^{13} \mathrm{C}$ record spanning the EECO. Base map is from http://www.odsn/de/services/paleomap.html with paleolatitudes modified for Sites 577, 1051 and 1258 according to www.paleolatitude.org model version 1.2 (Van Hinsbergen et al., 2015). Possagno paleolatitude is based on the http://www.odsn.de/odsn/services/paleomap/adv_map.html model since it is not yet available at http://www.odsn/de/services/ paleomap.html.

from three locations: the Possagno section from the western Tethys, Deep Sea Drilling Project (DSDP) Site 577 from the tropical Pacific Ocean and Ocean Drilling Program (ODP) Site 1051 from the subtropical Atlantic Ocean (Fig. 2). These sections represent a wide longitudinal span of low-latitude locations during the early Paleogene. By comparing stableisotope and planktic foraminiferal records at these three locations, we provide a new foundation for understanding why the abundances of Acarinina and Morozovella changed during the EECO.

\section{The Early Eocene Climatic Optimum}

Evidence for extreme Earth surface warmth during a multimillion-year time interval of the early Eocene is overwhelming and comes from many studies, utilizing both marine and terrestrial sequences and both fossil and geochemical proxies (Huber and Caballero, 2011; Hollis et al., 2012; Pross et al., 2012). However, a definition for the EECO, including the usage of "optimum", endures as a perplexing problem. This is for several reasons, including the basic facts that (i) proxies for temperature should not be used to define a time increment, (ii) clearly correlative records across the middle of the early Eocene with a temporal resolution of less than $50 \mathrm{kyr}$ remain scarce and (iii) absolute ages across the early Eocene have changed significantly (Berggren et al., 1995; Vandenberghe et al., 2102). As a consequence, various pa- pers discussing the EECO give different ages and durations 2 to $4 \mathrm{Myr}$ long sometime between circa 49 and $54 \mathrm{Ma}$ (e.g., Yapp, 2004; Lowenstein and Demicco, 2006; Zachos et al., 2008; Woodburne et al., 2009; Bijl et al., 2009; Smith et al., 2010; Hollis et al., 2012; Slotnick et al., 2012; Pujalte et al., 2015).

The EECO, at least as presented in many papers, refers to the time of minimum $\delta^{18} \mathrm{O}$ values in "stacked" benthic foraminifera stable-isotope curves (Fig. 1). These curves were constructed by splicing together multiple $\delta^{18} \mathrm{O}$ records generated at individual locations onto a common age model (originally Berggren et al., 1995). However, the stacked curves (Zachos et al., 2001, 2008; Cramer et al., 2009), while they can be adjusted to different timescales, show significant variance in $\delta^{18} \mathrm{O}$ across the middle to late early Eocene. Some of this variance is due to imprecisely calibrated records at individual sites, where cores do not align properly in the depth domain (Dickens and Backman, 2013). Some of this variance probably reflects a dynamic early Eocene climate regime, where average temperatures and atmospheric $p \mathrm{CO}_{2}$ across Earth changed significantly, perhaps on orbital timescales (Smith et al., 2010; Slotnick et al., 2012, 2015a; Kirtland-Turner et al., 2014).

There is also the root problem as to where EECO starts and ends. At a basic level, the interval characterized by the lowest Cenozoic benthic foraminiferal $\delta^{18} \mathrm{O}$ values begins at a time that closely corresponds with a long-term minimum in $\delta^{13} \mathrm{C}$ values (Fig. 1). This is important for stratigraphic 
reasons because the two stable-isotope curves were generated using the same benthic foraminiferal samples, but $\delta^{13} \mathrm{C}$ records at different locations should necessarily correlate in the time domain (unlike $\delta^{18} \mathrm{O}$ and temperature). The rationale for such a carbon isotope stratigraphy lies in the rapid cycling of carbon across Earth's surface (Shackleton, 1986; Dickens, 2000).

The Eocene minimum in $\delta^{13} \mathrm{C}$ corresponds to the $\mathrm{K} / \mathrm{X}$ event (Fig. 1), which happened in polarity Chron C24n.1n and approximately $3 \mathrm{Myr}$ after the PETM (Agnini et al., 2009; Leon-Rodriguez and Dickens, 2010; Slotnick et al., 2012; Dallanave et al., 2015; Lauretano et al., 2015; Westerhold et al., 2015). However, in several detailed studies spanning the early Eocene, changes in long-term trends appear to have occurred about $400 \mathrm{kyr}$ before the $\mathrm{K} / \mathrm{X}$ event and at an event called "J" (after Cramer et al., 2003), which happened near the boundary of polarity chrons C24n.2r and C24n.3n (Slotnick et al., 2015a; Lauretano et al., 2015). Notably, the long-term late-Paleocene-early Eocene decrease in detailed benthic foraminiferal $\delta^{18} \mathrm{O}$ records at Site 1262 on Walvis Ridge ceases at the J event (Lauretano et al., 2015).

The end of the EECO has received limited attention from a stratigraphic perspective. Indeed, the termination of the EECO may not be a recognizable global "event" because it may relate to ocean circulation and gateways expressed mostly in the Southern Ocean and deep-ocean records (Pearson et al., 2007; Bijl et al., 2013). In Paleogene continental slope sections now uplifted and exposed in the Clarence River valley, New Zealand, a major lithologic change from limestone to marl coincides with the J event (Slotnick et al., 2012, 2015a; Dallanave et al., 2015). The marl-rich unit, referred to as "Lower Marl", has been interpreted to reflect enhanced terrigenous supply to a continental margin because of greater temperature and enhanced seasonal precipitation. It has been suggested further that Lower Marl indicates the EECO (Slotnick et al., 2012; Dallanave et al., 2015). The top of Lower Marl, and a return to limestone deposition, lies within the upper part of polarity Chron C22n (Dallanave et al., 2015). This is interesting because it approximates the time when general long-term Cenozoic cooling is initiated at several locations that have records of polarity chrons and proxies for temperature (Bijl et al., 2009; Hollis et al., 2012; Pross et al., 2012). It is also useful from a stratigraphic perspective because the end of the EECO thus lies close to a well-documented and widespread calcareous nannofossil biohorizon, the base of Discoaster sublodoensis. This marks the base of CP10, NP12 or CNE4, depending on the chosen calcareous nannofossil zonal scheme (Okada and Bukry, 1980; Martini, 1971; Agnini et al., 2014).

Without an accepted definition in the literature, we tentatively present the EECO as the duration of time between the $\mathrm{J}$ event and the base of $D$. sublodoensis. This interval thus begins at about $53 \mathrm{Ma}$ and ends at about $49 \mathrm{Ma}$ on the 2012 Geologic Time Scale (GTS; Vandenberghe et al., 2012). However, while the EECO was characterized by generally warm conditions, numerous fluctuations in average temperature likely occurred during the $4 \mathrm{Myr}$ interval.

\section{Sites and stratigraphy}

\subsection{Possagno, Venetian Prealps, Tethys}

An Upper Cretaceous through Miocene succession crops out at the bottom of the Monte Grappa massif in the Possagno area, about $60 \mathrm{~km}$ northwest of Venice. The lower to middle Eocene, of primary focus in this study, is represented by the Scaglia beds. These sedimentary rocks represent pelagic and hemipelagic sediment that accumulated at middle to lower bathyal depths (Cita, 1975; Thomas, 1998) in the western part of the Belluno Basin, a Mesozoic-Cenozoic paleogeographic unit of the European Southern Alps (Bosellini, 1989). The basin very likely was an embayment connected to the western Tethys, with a paleolatitude of ca. $42^{\circ}$ during the early Eocene (Fig. 2).

A quarry at $45^{\circ} 51.0^{\prime} \mathrm{N}$ and $11^{\circ} 51.6^{\prime} \mathrm{E}$ exposed a $66 \mathrm{~m}$ thick section of the Scaglia beds in 2002-2003 (Fig. 3), although it is at present largely covered and inaccessible. This section was examined for its stratigraphy (Agnini et al., 2006; Luciani and Giusberti, 2014) and shown to extend from just below the PETM to within lower Chron C20r in the lower middle Eocene. Like other lower Paleogene sections of the Venetian Prealps (Giusberti et al., 2007; Agnini et al., 2016), a clay marl unit (CMU) with a prominent negative CIE marks the PETM.

The Possagno section appears to be continuous, but with an important decrease in sedimentation rate (to below $1.4 \mathrm{~m} \mathrm{Myr}^{-1}$ ) between 14.66 and $15.51 \mathrm{~m}$ (Agnini et al., 2006). This interval lies within Chron C23r and near the start of the EECO and predates the onset of a major increase in Discoaster abundance (Agnini et al., 2006).

\subsection{Site 577, Shatsky Rise, western Pacific}

DSDP Leg 86 drilled Site 577 at $32^{\circ} 26.5^{\prime} \mathrm{N}, 157^{\circ} 43.4^{\prime} \mathrm{E}$ and $2680 \mathrm{~m}$ water depth on Shatsky Rise, a large igneous plateau in the NW Pacific with a relatively thin veneer of sediment (Shipboard Scientific Party, 1985). During the early Eocene, this site was located closer to $15^{\circ} \mathrm{N}$ (Fig. 2), and probably at a slightly shallower water depth (Ito and Clift, 1998).

Two primary holes were drilled at Site 577. Both Hole 577* and Hole 577A recovered portions of a nominally $65 \mathrm{~m}$ thick section of Upper Cretaceous through lower Eocene nannofossil ooze. Similar to the Possagno section, the lower Paleogene interval has biomagnetostratigraphic information (Bleil, 1985; Monechi et al., 1985; Backman, 1986; Lu and Keller, 1995; Dickens and Backman, 2013). Stable-isotope records of bulk carbonate have been generated for sediment from several cores at low sample resolution (Shackleton, 1986) and for much of cores $577 *-9 \mathrm{H}$ and $577 *-10 \mathrm{H}$ at a fairly high sample resolution (Cramer et al., 2003). 

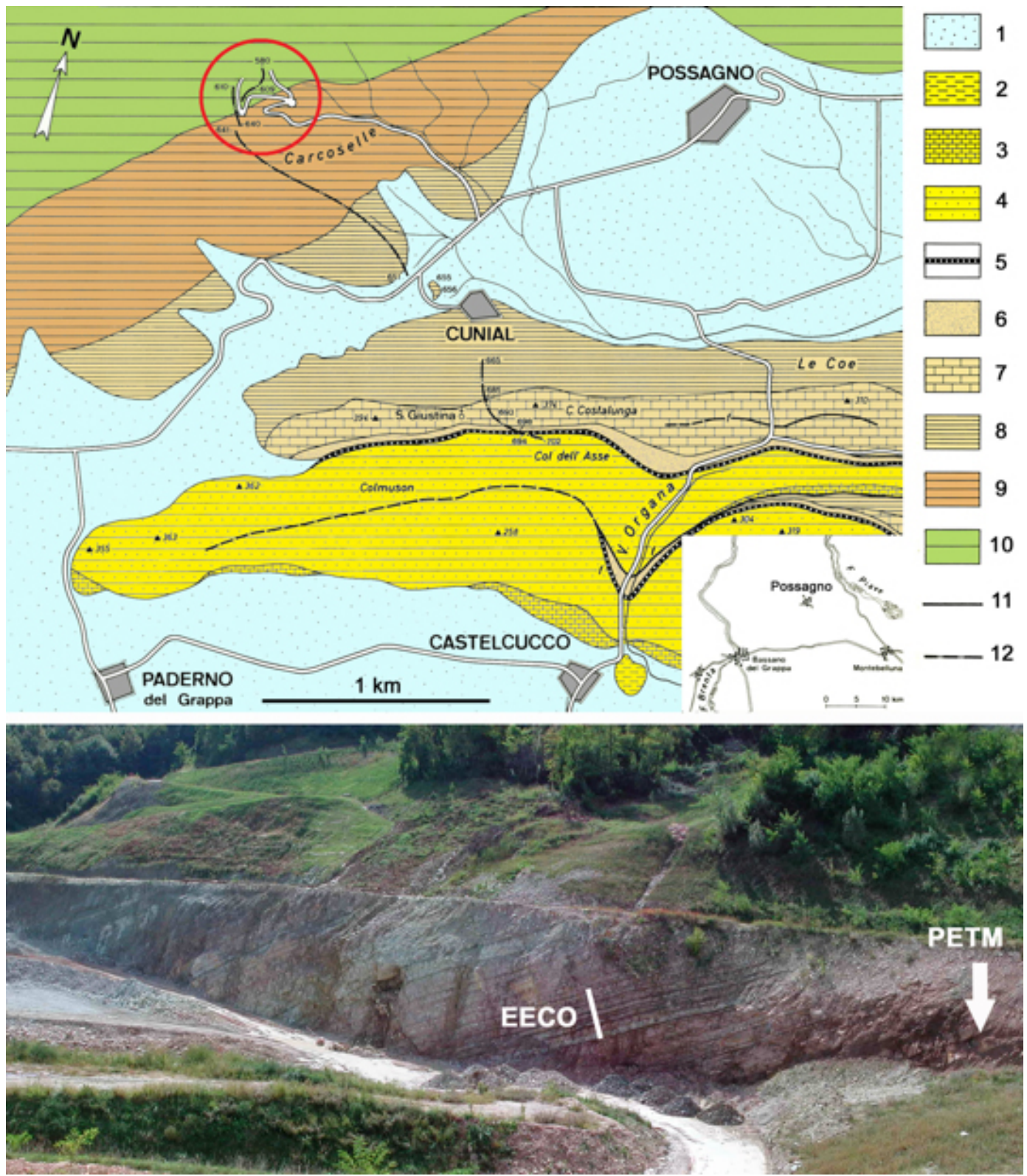

Figure 3. The Possagno section. Upper panel: geological map (modified from Braga, 1970). 1: Quaternary deposits; 2, 3: Calcarenite di Castelcucco (Miocene); 4: glauconitic arenites (Miocene); 5: siltstones and conglomerates (upper Oligocene-lower Miocene); 6: Upper Marna di Possagno (upper Eocene); 7: Formazione di Pradelgiglio (upper Eocene); 8: Marna di Possagno (upper Eocene); 9: Scaglia Cinerea (middle-upper Eocene); 10: Scaglia Rossa (Upper Cretaceous-lower Eocene); 11: faults; 12: traces of stratigraphic sections originally studied by Bolli (1975); red circle: the Carcoselle quarry. Lower panel: the exposed quarry face during Summer 2002 (Photo by Luca Giusberti).

The composition and relative abundances of planktic foraminifera were nicely documented at Site 577 (Lu, 1995; Lu and Keller, 1995) and show a marked turnover between Morozovella and Acarinina during the early Eocene. These data, however, relied on an outdated view of the stratigraphy at this location, where cores were not originally aligned to account for gaps and overlaps (Dickens and Backman, 2013). As will become obvious later, the main phase of the EECO spans cores $577 *-8 \mathrm{H}$ and $577 \mathrm{~A}-8 \mathrm{H}$, where detailed stableisotope records have not been generated previously.

\subsection{Site 1051, Blake Nose, western Atlantic}

The Blake Nose is a gentle ramp extending from 1000 to $2700 \mathrm{~m}$ water depth east of Florida (Norris et al., 1998). The feature is known for a relatively thick sequence of middle Cretaceous through middle Eocene sediment with minimal 
overburden. ODP Leg 171B drilled and cored this sequence at several locations, including Site 1051 at $30^{\circ} 03.2^{\prime} \mathrm{N}$, $76^{\circ} 21.5^{\prime} \mathrm{W}$ and $1994 \mathrm{~m}$ water depth (Shipboard Scientific Party, 1998). The site was located slightly to the south during the early Eocene (Fig. 2). Benthic foraminiferal assemblages indicate a lower bathyal depth (1000-2000 m) during the late Paleocene and middle Eocene (Norris et al., 1998), although Bohaty et al. (2009) estimated a paleodepth of about $2200 \mathrm{~m}$ for sedimentation at ca. $50 \mathrm{Ma}$.

Sediments from 452.24 to $353.10 \mathrm{~m}$ below the sea floor (m b.s.f. at Site 1051 consist of lower to middle Eocene carbonate ooze and chalk (Shipboard Scientific Party, 1998). The site comprises two holes (1051A and 1051B), with core gaps and core overlaps existing at both (Shipboard Scientific Party, 1998). However, the impact of these depth offsets upon age is less than at Site 577 because of higher overall sedimentation rates.

The Eocene section at Site 1051 has good sediment recovery, except in an interval between 382 and 390 m b.s.f., which contains significant chert. Stratigraphic markers across the Eocene interval include polarity chrons (Ogg and Bardot, 2001), calcareous nannofossil biohorizons (Mita, 2001) and planktic foraminiferal biohorizons (Norris et al., 1998; Luciani and Giusberti, 2014). As first noted by Cramer et al. (2003), though, there is a basic stratigraphic problem with the labeling of the polarity chrons. The intervals of normal polarity between approximately 388 and $395 \mathrm{~m}$ b.s.f. and between approximately 412 and $420 \mathrm{~m}$ b.s.f. were tentatively assigned to $\mathrm{C} 22 \mathrm{n}$ and $\mathrm{C} 23 \mathrm{n}$, respectively (Ogg and Bardot, 2001). This age assignment was assumed to be correct by Luciani and Giusberti (2014), who therefore considered the last occurrence of Morozovella subbotinae as happening near the top of $\mathrm{C} 23 \mathrm{n}$, an assumption that was also made for the revision of Eocene foraminiferal biozones (Wade et al., 2011).

These age assignments, however, cannot be correct because calcareous nannofossil biohorizons that lie below or within C22n (top of T. orthostylus, top of Toweius, base of D. sublodoensis) occur above $388 \mathrm{~m}$ b.s.f. (Mita, 2001). Instead, there must be a significant hiatus or condensed interval at the chert horizon, and the intervals of normal polarity noted above are C23n and C24n. $1 n$.

\section{Methods}

\subsection{Samples for isotopes and foraminifera}

The three sites provide a good stratigraphic background and the key existing data for understanding the temporal link between the EECO, carbon isotope perturbations and planktic foraminiferal evolution. Our analytical aim was to obtain comparable data sets across the sites. More specifically, a need existed to generate stable-isotope and planktic foraminiferal assemblage records at the Possagno section, to generate stable-isotope records at DSDP Site 577, and to gen- erate planktic foraminiferal assemblage records at ODP Site 1051 .

In total, 298 samples were collected from the originally exposed Possagno section in 2002-2003 for isotope analyses. The sampling interval was 2 to $5 \mathrm{~cm}$ for the basal $0.7 \mathrm{~m}$ and varied between 20 and $50 \mathrm{~cm}$ for the interval between 0.7 and $66 \mathrm{~m}$. Bulk sediment samples were previously examined for their calcareous nannofossil assemblages (Agnini et al., 2006). One hundred and ten of these samples were selected for the foraminiferal study.

Aliquots of the 110 samples were weighed and then washed to obtain foraminifera using two standard procedures, depending on lithology. For the indurated marly limestones and limestones, the cold-acetolysis technique was used (Lirer, 2000; Luciani and Giusberti, 2014). This method disaggregates strongly lithified samples, in which foraminifera can otherwise only be analyzed in thin sections (Fornaciari et al., 2007; Luciani et al., 2007). For the marls, samples were disaggregated using $30 \%$ hydrogen peroxide and subsequently washed and sieved at $63 \mu \mathrm{m}$. In most cases, gentle ultrasonic treatment (e.g., low-frequency at $40 \mathrm{kHz}$ for 30-60 s) improved the cleaning of the tests.

Relative abundance data of planktic foraminiferal samples were generated for 65 samples at Site 577 (Lu, 1995; Lu and Keller, 1995). We collected new samples for stable-isotope measurements that span their previous effort.

Fifty samples of Eocene sediment were obtained from Hole 1051A between 452 to $353 \mathrm{~m}$ b.s.f. Sample spacing varied from 2.0 to $0.5 \mathrm{~m}$. As the samples are ooze and chalk, they were prepared using disaggregation using distilled water and washing over 38 and $63 \mu \mathrm{m}$ sieves. Washed residues were dried at $<50^{\circ} \mathrm{C}$.

\subsection{Stable Isotopes}

Carbon and oxygen stable-isotope data of bulk sediment samples from the Possagno section and Site 577 were analyzed using a Finnigan MAT 252 mass spectrometer equipped with a Kiel device at Stockholm University. Precision is within $\pm 0.06 \%$ for carbon isotopes and within $\pm 0.07 \%$ o for oxygen isotopes. Stable-isotope values were calibrated to the Vienna Pee Dee Belemnite standard (VPDB) and converted to conventional delta notation $\left(\delta^{13} \mathrm{C}\right.$ and $\left.\delta^{18} \mathrm{O}\right)$.

\subsection{Foraminiferal analyses}

The mass percent of the $>63 \mu \mathrm{m}$ size fraction relative to the mass of the bulk sample, typically $100 \mathrm{~g} \mathrm{sample}^{-1}$, was calculated for the 110 Possagno samples. This is referred to as the weight percent coarse fraction (CF), following many previous works. Due to the consistent occurrence of radiolarians at Site 1051, the CF cannot give information on foraminiferal productivity. 
Relative abundances for both Possagno and Site 1051 have been determined from about 300 complete specimens extracted from each of the 110 samples investigated in the $>63 \mu \mathrm{m}$ size fraction from random splits.

The degree of dissolution, expressed as the fragmentation index $(F$-index) was evaluated according to Petrizzo et al. (2008) on ca. 300 elements by counting planktic foraminiferal fragments or partially dissolved tests versus complete tests. These data are expressed in percentages. Fragmented foraminifera include specimens showing missing chambers and substantial breakage. The taxonomic criteria for identifying planktic foraminifera follow the work by Pearson et al. (2006).

\section{Results}

\subsection{Carbon isotopes}

\subsubsection{Possagno}

Carbon isotopes of bulk carbonate at Possagno vary between +1.8 and $-0.3 \%$ o (Fig. 4, Supplement Table S1). Overall, $\delta^{13} \mathrm{C}$ decreases from $1.8 \%$ at the base of the section to about $0.6 \%$ at $14 \mathrm{~m}$. Generally, values then increase to $1.5 \%$ at $24 \mathrm{~m}$ and remain between 1.5 and $0.8 \%$ for the remainder of the studied interval.

Superimposed on these trends are a series of negative CIEs. The most prominent of these $(\sim 1.5 \%)$ occurs at the $0 \mathrm{~m}$ level, and marks the PETM (Agnini et al., 2009). However, other negative CIEs lie above this marker and within the lowermost $21.4 \mathrm{~m}$, although some are only defined by one data point (Fig. 4, Table S1). The lower two, at $\sim 8$ and $\sim 12.5 \mathrm{~m}$, probably represent the H-1/ETM- 2 and $\mathrm{J}$ event, respectively, as they lie at the appropriate stratigraphic horizons in relation to polarity chrons. The $\mathrm{K} / \mathrm{X}$ event may lie at $14.8 \mathrm{~m}$, although this height marks the start of the condensed interval.

The complex interval between 15.5 and $24 \mathrm{~m}$ broadly corresponds to all of Chron C23n and the bottom half of Chron C22r. A series of CIEs occur in that interval on the order of $1.4 \%$, superimposed on a background trend of increasing $\delta^{13} \mathrm{C}$ values (about $0.7 \%$ ). We tentatively label these CIEs with even numbers for internal stratigraphic purposes (Fig. 4), as will become obvious below; their magnitudes range between 0.9 and $0.3 \%$ (Table S1). However, the sample spacing through this interval varies from 20 to $50 \mathrm{~cm}$. The precise magnitudes and positions certainly could change with higher sample resolution, given the estimated compacted sedimentation rate of $\sim 0.5 \mathrm{~cm} \mathrm{kyr}^{-1}$ for this part of the section (Agnini et al., 2006).

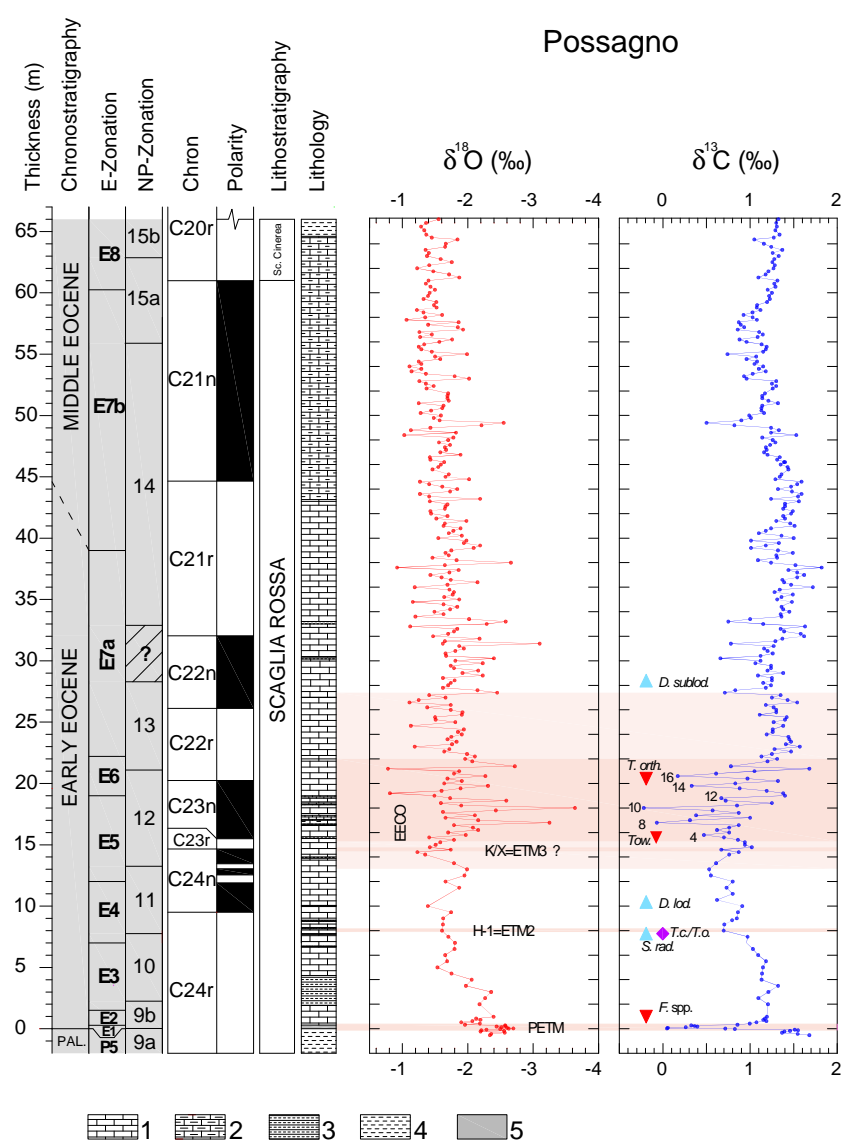

Figure 4. Lithology, stratigraphy and bulk sediment stable-isotope composition of the Possagno section aligned according to depth. Litholologic key: 1 - limestone; 2 - marly limestone and calcareous marl; 3 - cyclical marl-limestone alternations, 4 - marl; 5 - clay marl unit (CMU). Planktic foraminiferal biozones follow those of Wade et al. (2011), as modified by Luciani and Giusberti (2014). Magnetostratigraphy and key calcareous nannofossil events come from Agnini et al. (2006); NP-zonation is from Martini (1971). Nannofossil events are shown as red triangles (tops), blue triangles (bases) and purple diamonds (evolutionary crossovers); S. rad.: Sphenolithus radians; T.c./T.o.: Tribrachiatus contortus/Tribrachiatus orthostylus; D. lod.: Discoaster lodoensis; Tow.: Toweius; T. orth.: Tribrachiatus orthostylus; D. sublod.: Discoaster sublodoensis. Stable-isotope records determined in this study. Established early Eocene "events" are superimposed in light red; suggested carbon isotope excursions (CIEs) within the EECO are shown with numbers.

Above Chron C22r, the Possagno $\delta^{13} \mathrm{C}$ record contains additional minor CIEs (Fig. 4). The most prominent of these CIEs, at least relative to baseline values $(\sim 1.2 \%$ o), occurs within Chron $\mathrm{C} 21 \mathrm{n}$. More important to understanding the EECO, a $\sim 0.6 \%$ CIE nearly coincides with the base of $D$. sublodoensis within the lower part of Chron C22n. 


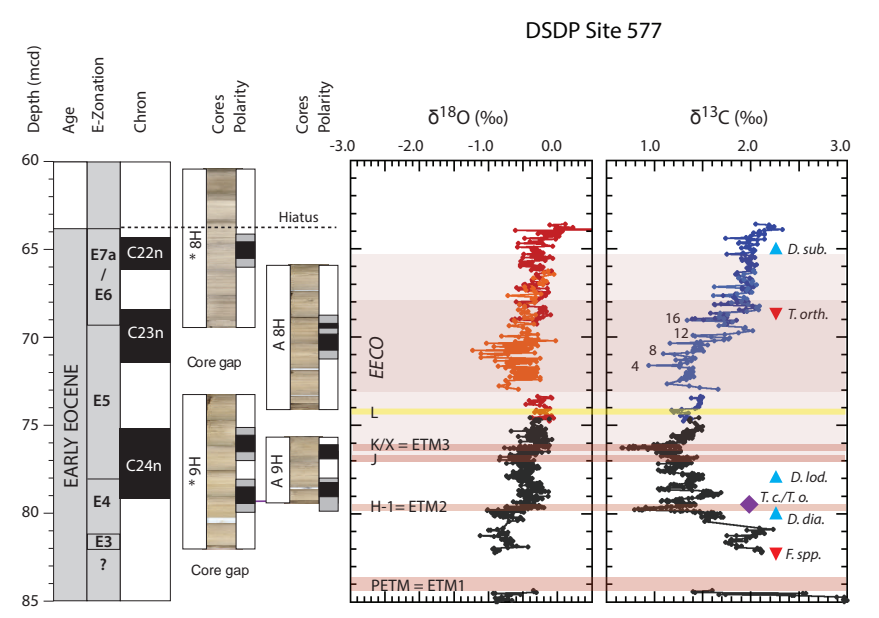

Figure 5. Cores, stratigraphy and bulk sediment stable-isotope composition for the early Eocene interval at Deep Sea Drilling Project (DSDP) Site 577 aligned according to composite depth (Dickens and Backman, 2013). Note the increased length for the gap between Core $577 *-8 \mathrm{H}$ and Core $577 *_{-} 9 \mathrm{H}$ (see text). The Wade et al. (2011) E-zonation, partly modified by Luciani and Giusberti (2014), has been applied to Site 577, given assemblages presented by Lu (1995) and Lu and Keller (1995). Note that (i) the base of Zone E3 (top of Morozovella velascoensis) lies within a core gap; (ii) the E4-E5 zonal boundary (base of M. aragonensis) occurs within C24n, in agreement with Luciani and Giusberti (2014); (iii) the E5-E6 zonal boundary is problematic because the top of M. subbotinae occurs in the middle of $\mathrm{C} 24 \mathrm{n}$, much earlier than the presumed disappearance in the upper part of C23n (Wade et al., 2011), and we have therefore positioned the E5-E6 boundary at the lowest occurrence of Acarinina aspensis, according to the original definition of Zone E5 (Berggren and Pearson, 2005); and (iv) we cannot differentiate between Zone E6 and Zone E7a due to the absence of Astrorotalia palmerae and to the diachronous appearance of A. cuneicamerata (Luciani and Giusberti, 2014). Magnetostratigraphy and key calcareous nannofossil events are those summarized by Dickens and Backman (2013). These events noted in Fig. 4 are abbreviated as follows here and in the following figures: $F$. spp. Fasciculithus spp.; D. dia. - Discoaster diastypus. Stable-isotope records: black - Cramer et al. (2003); red and blue - this study. Early Eocene events are the same as those in Fig. 4.

\subsubsection{DSDP Site 577}

The $\delta^{13} \mathrm{C}$ record of bulk carbonate at DSDP Site 577 from just below the PETM through Chron $\mathrm{C} 22 \mathrm{n}$ ranges between 2.3 and $0.6 \%$ (Fig. 5; Table S2). Overall, $\delta^{13} \mathrm{C}$ decreases from $1.4 \%$ at 84.5 meters composite depth (mcd) to about $0.6 \%$ at $\sim 76 \mathrm{mcd}$. Values then generally increase to $2.1 \%$ o at $\sim 68 \mathrm{mcd}$ and remain between 2.3 and $1.6 \%$ or the rest of the studied interval. Thus, the ranges and general trends in $\delta^{13} \mathrm{C}$ for the two sections are similar but skewed at DSDP Site 577 relative to Possagno by about $+0.6 \%$.

Like at Possagno, the early Eocene $\delta^{13} \mathrm{C}$ record at DSDP Site 577 exhibits a series of CIEs (Fig. 5). The portion of this record from the PETM through the K/X event has been docu- mented and discussed elsewhere (Cramer et al., 2003; Dickens and Backman, 2013). The new portion of this record, from above the $\mathrm{K} / \mathrm{X}$ event through Chron $\mathrm{C} 22 \mathrm{n}$, spans the remainder of the EECO. Within this interval, where background $\delta^{13} \mathrm{C}$ values rise by $\sim 1.5 \%$, there again occurs a series of minor CIEs with magnitudes between 0.3 and $0.5 \%$ o (Table S2). Here, however, multiple data points define most of the CIEs. We again give these an internal numerical labeling scheme. A $\sim 0.4 \%$ CIE also nearly coincides with the base of D. sublodoensis within the lower part of C22n.

\subsection{Oxygen isotopes}

\subsubsection{Possagno}

Oxygen isotopes of bulk carbonate at Possagno range between -3.3 and $0.8 \%$, with a mean value of $-1.7 \%$ (Fig. 4 , Table S1). In general, considerable scatter exists across the data set with respect to depth, as adjacent samples often display a difference in $\delta^{18} \mathrm{O}$ that exceeds $0.5 \%$. Nonetheless, some of the more prominent lows in $\delta^{18} \mathrm{O}$ show a clear correspondence with negative $\delta^{13} \mathrm{C}$ values (CIEs) and vice versa. This correspondence occurs across the PETM and other known hyperthermals, as well as within and after the EECO. Indeed, the main phase of the EECO corresponds to an interval with the lowest $\delta^{18} \mathrm{O}$ values.

\subsubsection{DSDP Site 577}

The $\delta^{18} \mathrm{O}$ record at Site 577 noticeably deviates from that at Possagno (Fig. 5, Table S2). This is because values range between $-1.1 \%$ and 0.2 , with an average value of $-0.4 \%$. Thus, relative to Possagno, the record at Site 577 has less scatter and an overall shift of about $-1.3 \%$. There is again a modest correlation between decreases in $\delta^{18} \mathrm{O}$ and negative $\delta^{13} \mathrm{C}$ values, as well as a general low in $\delta^{18} \mathrm{O}$ across the main phase of the EECO.

\subsection{Coarse fraction}

The coarse fraction of samples from Possagno shows two distinct trends (Fig. 6, Table S3). Before the EECO, values are $10.4 \% \pm 2.67 \%$. However, from the base of the EECO and up through the section, values decrease to $5.3 \% \pm 1.3 \%$.

\subsection{Foraminiferal preservation and fragmentation}

Planktic foraminifera are consistently present and diverse throughout the studied intervals at Possagno and at ODP Site 1051. Preservation of the tests at Possagno varies from moderate to fairly good (Luciani and Giusberti, 2014). However, planktic foraminiferal tests at Possagno are recrystallized and essentially totally filled with calcite. Planktic foraminifera from samples at Site 1051 are readily recognizable throughout the studied interval. Planktic foraminifera from Site 577, at least as illustrated by published plates ( $\mathrm{Lu}$ and Keller, 


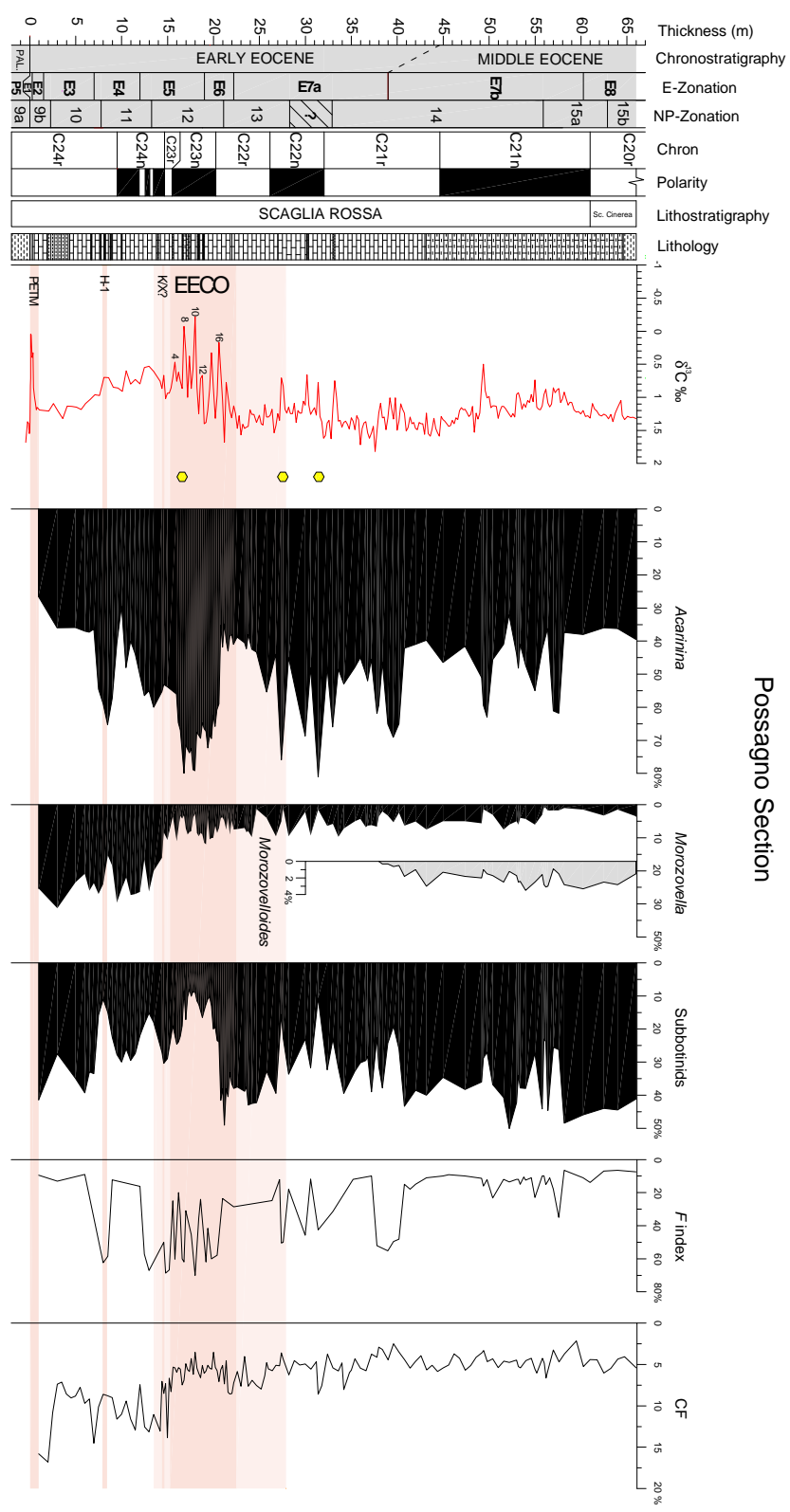

Figure 6. The Possagno section and its $\delta^{13} \mathrm{C}$ record (Fig. 4) with measured relative abundances of primary planktic foraminiferal genera, fragmentation index ( $F$-index) and coarse fraction $(\mathrm{CF})$. The subbotinid abundance includes both Subbotina and Parasubbotina genera. Note that a significant increase in Acarinina abundance marks the EECO and several carbon isotope excursions (CIEs). Note also the major decline in abundance of Morozovella at the start of the EECO. Filled yellow hexagons show occurrences of abundant radiolarians. Lithological symbols and early Eocene events are the same as those in Fig. 4.

1995), show a very good state of preservation (albeit possibly recrystallized).

The $F$-index record at Possagno (Fig. 6, Table S3) displays large-amplitude variations throughout the investigated inter- val. The highest values, up to $70 \%$, were observed between 16 and $22 \mathrm{~m}$. In general, highs in $F$-index values correspond to lows in the $\delta^{13} \mathrm{C}$ record.

The $F$-index record at Site 1051 (Fig. 8, Table S4) shows less variability compared to that at Possagno, although some of this may reflect the difference in the number of samples examined at the two locations. A maximum value of $60 \%$ is found in Zone E5, just below an interval of uncertain magnetostratigraphy (Norris et al., 1998) but corresponding to the J event (Cramer et al., 2003). Relatively high $F$-index values, around $50 \%$, also occur in several samples below this horizon. The interval across the EECO generally displays low $F$-index values $(<20 \%)$.

\subsection{Planktic foraminiferal quantitative analysis}

\subsubsection{Possagno}

Planktic foraminiferal assemblages at Possagno show significant changes across the early to early middle Eocene (Fig. 6, Table S3). Throughout the entire section, the mean relative abundance of Acarinina is about $46 \%$ of the total assemblage. However, members of this genus exhibit peak abundances of $60-80 \%$ of the total assemblage across several intervals, often corresponding to CIEs. Particularly prominent is the broad abundance peak of Acarinina coincident with the main phase of the EECO.

The increases in Acarinina relative abundance typically are counterbalanced by transient decreases in subbotinids (which include both Subbotina and Parasubbotina genera; Fig. 6). This group also shows a general increase throughout the section. Below the EECO the relative abundances of subbotinids average $\sim 24 \%$. Above the EECO, this average rises to $\sim 36 \%$.

The trends in Acarinina and subbotinids contrast with that in Morozovella (Fig. 6), which exhibits a major and permanent decline within Zone E5. This group collapses from mean abundances $\sim 24 \%$ in the $0-15 \mathrm{~m}$ interval to $<6 \%$ above $15 \mathrm{~m}$. Qualitative examination of species shows that, in the lower part of Zone E5, where relatively high Morozovella abundances are recorded, there is no dominance of any species. M. marginodentata, M. subbotinae and M. lensiformis are each relatively common, and $M$. aequa, $M$. aragonensis, M. formosa and M. crater are each less common. By contrast, in the upper part of Zone E5, where low abundances of Morozovella occur, M. aragonensis, M. formosa, M. crater and $M$. caucasica are the most common species. The general decrease in Morozovella abundances appears unrelated to the disappearance of a single, dominant species.

At Possagno, Morozovella never recover to their preEECO abundances. This is true even if one includes the morphologically and ecologically comparable genus Morozovelloides (Pearson et al., 2006), which first appears in samples above $36 \mathrm{~m}$. 


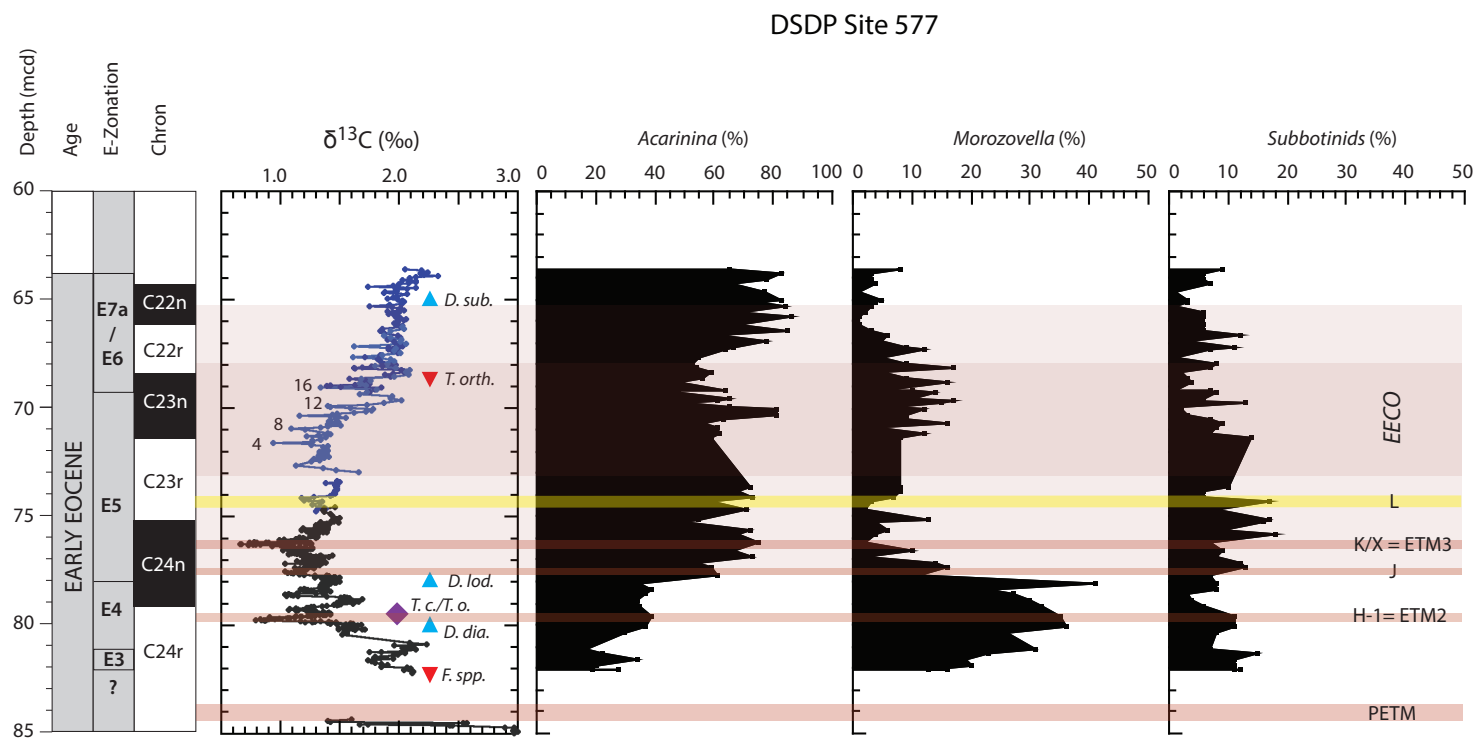

Figure 7. The early Eocene succession at DSDP Site 577 and its $\delta^{13} \mathrm{C}$ record (Fig. 5) with relative abundances of primary planktic foraminiferal genera (Lu, 1995; Lu and Keller, 1995). Note that the major switch in Morozovella and Acarinina abundances approximately coincides with the $\mathrm{J}$ event, the top of polarity Chron $\mathrm{C} 24 \mathrm{n}$ and the start of the EECO. Calcareous nannofossil horizons are the same as in previous figures. Early Eocene events are the same as those in Fig. 4.

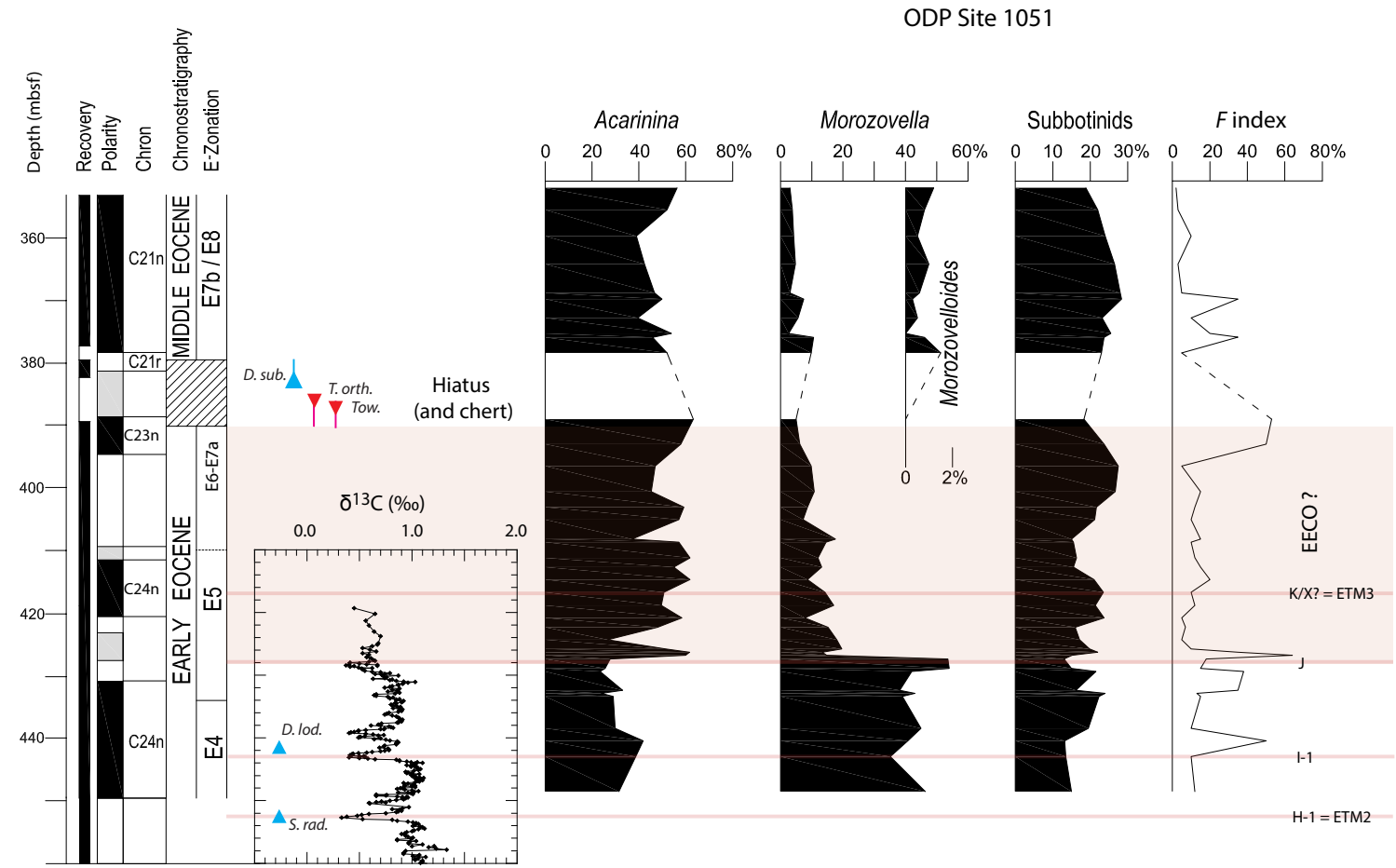

Figure 8. Stratigraphy, bulk sediment $\delta^{13} \mathrm{C}$ composition, relative abundances of primary planktic foraminiferal genera and fragmentation index $(F$-index) for the early Eocene interval at ODP Site 1051. Planktic foraminiferal biozones follow those of Wade et al. (2011), as modified by Luciani and Giusberti (2014; see Fig. 1 caption). Magnetostratigraphy and positions of key calcareous nannofossil events come from Ogg and Bardot (2001) and Mita (2001), but with an important modification to polarity chron labeling (see text and Cramer et al., 2003). Calcareous nannofossil horizons are the same as in previous figures. Foraminferal information comes from this study; subbotinids include both Subbotina and Parasubbotina. Early Eocene events are the same as those in Fig. 4. 
Other planktic foraminiferal genera are always less than $15 \%$ of the total assemblages throughout the studied interval at Possagno (Supplement Fig. S1, Table S3).

\subsubsection{ODP Site 577}

Samples from Site 577 were disaggregated in water and washed through a > 63 sieve (Lu, 1995; Lu and Keller, 1995). $\mathrm{Lu}$ and Keller determined relative abundances of planktic foraminifera from random splits of about 300 specimens ( $\mathrm{Lu}$, 1995; Lu and Keller, 1995). The resulting data are shown in Fig. 7, placed onto the composite depth scale of Dickens and Backman (2013). Major changes in planktic foraminiferal assemblages are comparable to those recorded at Possagno. Indeed, such changes include a distinct decrease in Morozovella within Zone E5. The decrease at Site 577 is from mean values of 26.6 to $6.7 \%$ (Table S4). This marked drop occurs at ca. $78 \mathrm{mcd}$, close to the $\mathrm{J}$ event and at the start of the EECO. Like at Possagno, Morozovella never recover to their pre-EECO abundances.

The Morozovella decrease is counterbalanced by the trend in Acarinina abundances that increase from mean values of 30.4 to $64.8 \%$, corresponding to the level of the Morozovella collapse. Subbotinids fluctuate in abundance throughout the interval investigated from 1 to $18 \%$, with a mean value of ca. $8 \%$.

\subsubsection{ODP Site 1051}

Planktic foraminifera show distinct changes in abundance at Site 1051 (Fig. 8, Table S5). The changes in the main taxa are similar to the variations observed at Possagno. The genus Acarinina displays an increase in mean relative abundance from $35 \%$ (base to ca. $450 \mathrm{mb}$ b.s.f.) to around $50 \%$ (ca. $430 \mathrm{~m}$ b.s.f.), with maximum values of about $60 \%$. The relatively low resolution used here does not permit comparison to the early Eocene CIEs at Site 1051 (Cramer et al., 2003) or determining how the relative abundance of planktic foraminiferal genera varies with respect to CIEs.

The abundance of subbotinids shows small variations around mean values of $20 \%$ at Site 1051. Like at Possagno, samples from Site 1051 also record a slight increase in abundance toward the end of the EECO and above.

The major change in planktic foraminiferal assemblages at Site 1051 includes a distinct decrease in Morozovella, from mean values around 40 to $10 \%$ in the middle part of Zone E5 (Fig. 7). Similar to Possagno, the lower part of Zone E5 with the higher percentages of Morozovella does not record the dominance of selected species, but at Site 1051 $M$. aragonensis and $M$. formosa as well as $M$. subbotinae are relatively common, whereas $M$. marginodentata is less frequent. Within the interval of low Morozovella abundances, M. aragonensis and M. formosa are the most common taxa. The general decline in Morozovella does not therefore ap- pear to be related, neither at Possagno nor at Site 1051, to the extinction or local disappearance of a dominant species.

\section{Discussion}

\subsection{Dissolution, recrystallization and bulk carbonate stable isotopes}

The bulk carbonate stable-isotope records within the lower Paleogene sections at Possagno and at Site 577 need some reflection, considering how such records are produced and modified in much younger strata dominated by pelagic carbonate. In open-ocean environments, carbonate preserved on the seafloor principally consists of calcareous tests of nannoplankton (coccolithophores) and planktic foraminifera (Bramlette and Riedel, 1954; Berger, 1967; Vincent and Berger, 1981). However, the total amount of carbonate and its microfossil composition can vary considerably across locations because of differences in deep-water chemistry and in test properties (e.g., ratio of surface area to volume, mineralogical composition). For regions at mid- to low latitudes, a reasonable representation of carbonate components produced in the surface water accumulates on the seafloor at modest $(<2000 \mathrm{~m})$ water depth. By contrast, microfossil assemblages become heavily modified in deeper water because of increasingly significant carbonate dissolution (Berger, 1967). Such dissolution preferentially affects certain tests, such as thin-walled, highly porous planktic foraminifera (Berger, 1970; Bé et al., 1975; Thunell and Honjo, 1981).

The stable-isotope composition of modern bulk carbonate ooze reflects the mixture of its carbonate components, which mostly record water temperature and the composition of dissolved inorganic carbon (DIC) within the mixed layer (<100 m water depth). The stable-isotope records are imperfect, though, because of varying proportions of carbonate constituents and "vital effects", which impact stable-isotope fractionation for each component (Anderson and Cole, 1975; Reghellin et al., 2015). Nonetheless, the stable-isotope composition of bulk carbonate ooze on the seafloor can be related to overlying temperature and chemistry of surface water (Anderson and Cole, 1975; Reghellin et al., 2015).

Major modification of carbonate ooze occurs during sediment burial. This is because, with compaction and increasing pressure, carbonate tests begin to dissolve and recrystallize (Schlanger and Douglas, 1974; Borre and Fabricus, 1998). Typically within several hundred meters of the seafloor, carbonate ooze becomes chalk and, with further burial, limestone (Schlanger and Douglas, 1974; Kroenke et al., 1991; Borre and Fabricus, 1998). Carbonate recrystallization appears to be a local and nearly closed-system process, such that mass transfer occurs over short distances (i.e., less than a few meters) (Schlanger and Douglas, 1974; Matter et al., 1975; Arthur et al., 1984; Kroenke et al., 1991; Borre and Fabricus, 1998; Frank et al., 1999). 
In pelagic sequences with appreciable carbonate content and low organic carbon content, bulk carbonate $\delta^{13} \mathrm{C}$ records typically give information of paleoceanographic significance (Scholle and Arthur, 1980; Frank et al., 1999). Even when transformed to indurated limestone, the $\delta^{13} \mathrm{C}$ value for a given sample should be similar to that originally deposited on the seafloor. This is because, for such sediments, almost all carbon in small volumes exists as carbonate. Bulk carbonate $\delta^{18} \mathrm{O}$ records are a different matter, especially in indurated marly limestones and limestones (Marshall, 1992; Schrag et al., 1995; Frank et al., 1999). This is because pore water dominates the total amount of oxygen within an initial parcel of sediment, and oxygen isotope fractionation depends strongly on temperature. Thus, during dissolution and recrystallization of carbonate, a significant exchange of oxygen isotopes occurs. At first, carbonate begins to preferentially acquire ${ }^{18} \mathrm{O}$ because shallowly buried sediment generally has lower temperatures than surface water. However, with increasing burial depth along a geothermal gradient, carbonate begins to preferentially acquire ${ }^{16} \mathrm{O}$ (Schrag et al., 1995; Frank et al., 1999).

\subsection{Carbon isotope stratigraphy through the EECO}

Stratigraphic issues complicate direct comparison of various records from Possagno and Site 577. The two sections have somewhat similar multi-million-year sedimentation rates across the early Eocene. However, the section at Possagno contains the condensed interval, where much of C23r spans a very short distance (Agnini et al., 2006), and the section at Site 577 has a series of core gaps and core overlaps (Dickens and Backman, 2013).

An immediate issue to amend is the alignment of cores $8 \mathrm{H}$ and $9 \mathrm{H}$ in Hole 577* and Core $8 \mathrm{H}$ in Hole 577A (Fig. 5). On the basis of Gamma Ray Porosity Evaluator (GRAPE) density records for these cores, Dickens and Backman (2013) initially suggested a $2.6 \mathrm{~m}$ core gap between cores $8 \mathrm{H}^{*}$ and $9 \mathrm{H}^{*}$. However, a $3.5 \mathrm{~m}$ core gap also conforms to all available stratigraphic information. The newly generated $\delta^{13} \mathrm{C}$ (and $\delta^{18} \mathrm{O}$ ) records across these three cores show the latter to be correct.

Once sedimentation rate differences at Possagno are recognized and coring problems at Site 577 are rectified, early Eocene $\delta^{13} \mathrm{C}$ records at both locations display similar trends and deviations in relation to polarity chrons and key microfossil events (Figs. 4, 5). Moreover, the $\delta^{13} \mathrm{C}$ variations seemingly can be correlated in time to those found in bulk carbonate $\delta^{13} \mathrm{C}$ records at other locations, including Site 1051 (Fig. 8) and Site 1258 (Fig. 9). As noted previously, such correlation occurs because the bulk carbonate $\delta^{13} \mathrm{C}$ signals reflect past global changes in the composition of surface water DIC, even after carbonate recrystallization.

For the latest Paleocene and earliest Eocene, nominally the time spanning the period from the base of $\mathrm{C} 24 \mathrm{r}$ through the middle of $\mathrm{C} 24 \mathrm{n}$, detailed stable carbon isotope records have been generated at more than a dozen locations across the globe (Cramer et al., 2003; Agnini et al., 2009, 2016; Galeotti et al., 2010; Zachos et al., 2010; Slotnick et al., 2012; Littler et al., 2014). These records can be described consistently as a long-term drop in $\delta^{13} \mathrm{C}$ superimposed with a specific sequence of prominent CIEs that include those corresponding to the PETM, H-1 and J events. In continuous sections with good magnetostratigraphy and biostratigraphy, there is no ambiguity in the assignment of CIEs (Zachos et al., 2010; Littler et al., 2014; Slotnick et al., 2012, 2105a; Lauretano et al., 2015). This " $\delta{ }^{13} \mathrm{C}$ template" can be found at the Possagno section and at Site 577 (Fig. 9); it is found at Site 1051 for the depth interval where carbon isotopes have been determined (Fig. 8).

For the period after the J event and across the EECO, very few detailed $\delta^{13} \mathrm{C}$ records have been published (Slotnick et al., 2012, 2015a; Kirtland-Turner et al., 2014). Moreover, the available records are not entirely consistent. For example, the $\mathrm{K} / \mathrm{X}$ event in Clarence River valley sections manifests as a prominent $\mathrm{CIE}$ within a series of smaller $\delta^{13} \mathrm{C}$ excursions (Slotnick et al., 2012, 2015a), whereas the event has limited expression in the $\delta^{13} \mathrm{C}$ record at Site 1258 (Kirtland-Turner et al., 2014; Fig. 9).

The new records from Possagno and Site 577 emphasize an important finding regarding bulk carbonate $\delta^{13} \mathrm{C}$ records across the EECO. Between the middle of $\mathrm{C} 24 \mathrm{n}$ and the upper part of $\mathrm{C} 23 \mathrm{r}$, there appears to be a sequence of lowamplitude, low-frequency CIEs. (Note that this portion of the record is missing at Possagno because of the condensed interval; Fig. 9.) However, near the $\mathrm{C} 23 \mathrm{r}-\mathrm{C} 23 \mathrm{n}$ boundary, a long-term rise in $\delta^{13} \mathrm{C}$ begins but with a series of relatively high-amplitude, high-frequency CIEs (Kirtland-Turner et al., 2014; Slotnick et al., 2014). The number, relative magnitude and precise timing of CIEs within this interval remain uncertain. For example, the CIE labeled "4" appears to occur near the top of C23r at Site 577 but near the bottom of C23n.2n at Site 1258 and at Possagno. Additional $\delta^{13} \mathrm{C}$ records across this interval are needed to resolve the correct sequence of CIEs and to derive an internally consistent labeling scheme for these perturbations. It is also not clear which of these CIEs during the main phase of the EECO specifically relate to significant increases in temperature, as is clear for the "hyperthermals" in the earliest Eocene. Nonetheless, numerous CIEs, as well as an apparent change in the mode of these events, characterize the EECO (Kirtland-Turner et al., 2014; Slotnick et al., 2014).

The causes of $\delta^{13} \mathrm{C}$ changes during the early Paleogene lie at the heart of considerable research and debate (Dickens et al., 1995, 1997; Zeebe et al., 2009; Dickens, 2011; Lunt et al., 2011; Sexton et al., 2011; DeConto et al., 2012; Lee et al., 2013; Kirtland-Turner et al., 2014). Much of the discussion has revolved around three questions. (1) What are the sources of ${ }^{13} \mathrm{C}$-depleted carbon that led to prominent CIEs, especially during the PETM? (2) Does the relative importance of different carbon sources vary through- 
A. Possagno, northeast Italy

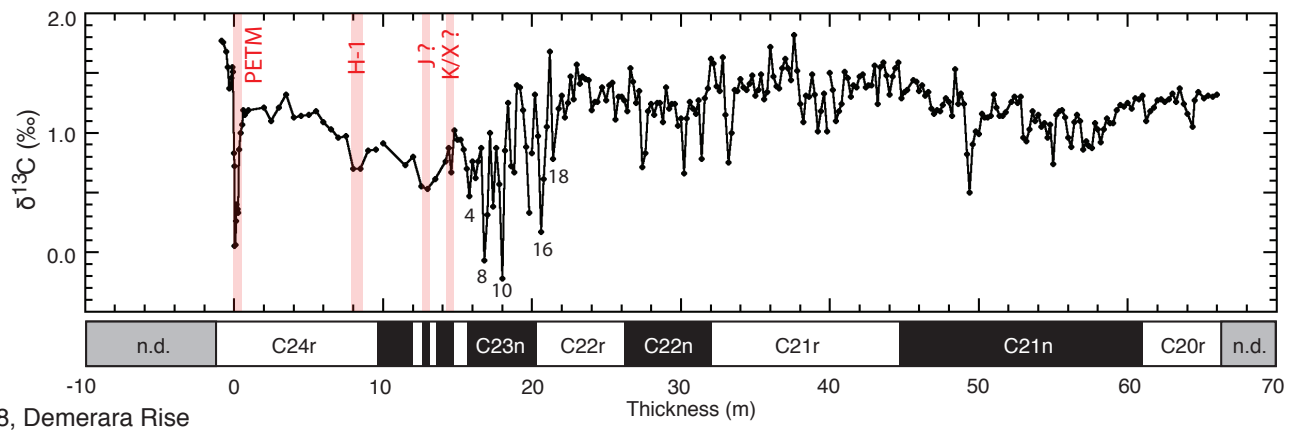

B. ODP Site 1258, Demerara Rise

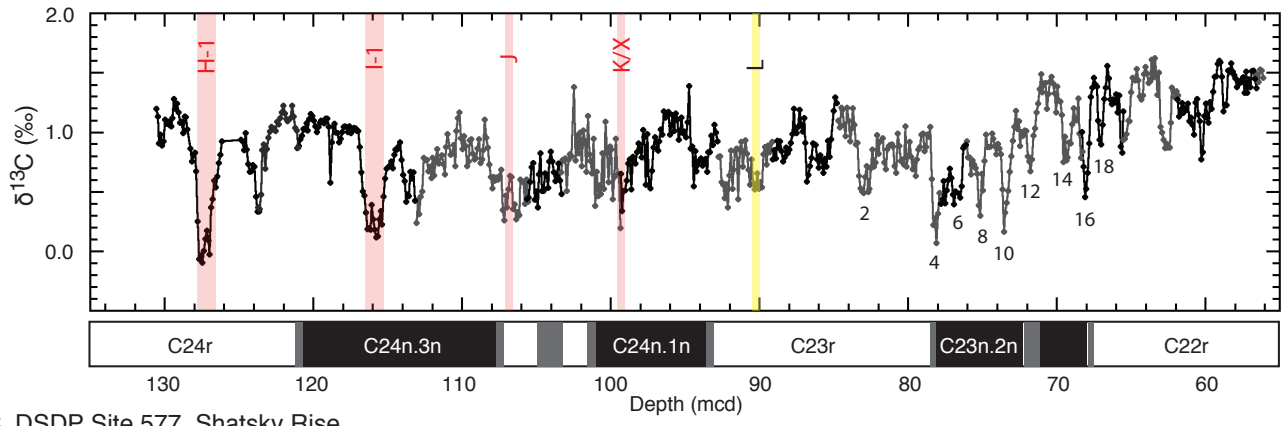

C. DSDP Site 577 , Shatsky Rise

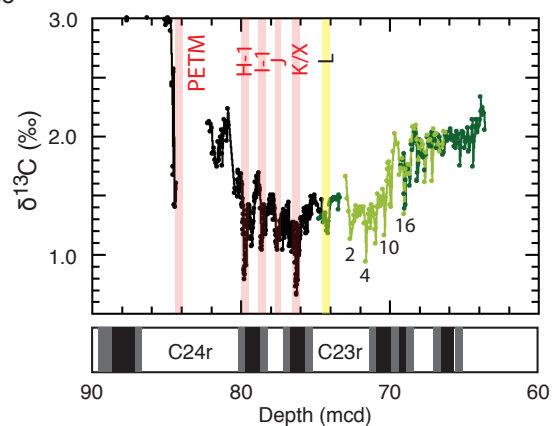

Figure 9. Carbon isotope and paleomagnetic records across the early Eocene for the Possagno section, DSDP Site 577 and ODP Site 1258 (Kirtland-Turner et al., 2014). This highlights the overall framework of carbon cycling in the early Eocene but also stratigraphic problems across the EECO at each of the three sites. At Possagno, the coarse resolution of $\delta^{13} \mathrm{C}$ records and the condensed interval make correlations difficult. At ODP Site 1258 the prominent K/X event seems missing. At DSDP Site 577, the entire record is compressed in the depth domain. Nonetheless, a major shift in frequency and amplitude of carbon isotope excursions (CIEs) appears to have happened during the EECO. CIEs that may correlate within the EECO are shown with numbers.

out this time interval? (3) Are the geologically brief CIEs related to the longer secular changes in $\delta^{13} \mathrm{C}$ ? One may see in several papers, a convergence of thought on how carbon cycled across Earth's surface during the early Paleogene, at least between the late Paleocene and the K/X event (Cramer et al., 2003; Lourens et al., 2005; Galeotti et al., 2010; Hyland et al., 2013; Zachos et al., 2010; Lunt et al., 2011; Littler et al., 2014; Lauretano et al., 2015; Westerhold et al., 2015). Changes in, tectonism, volcanism and weathering drove long-term changes in atmospheric $p \mathrm{CO}_{2}$ (Vogt, 1979; Raymo and Ruddiman, 1992; Sinton and Duncan, 1998; Demicco, 2004; Zachos et al., 2008), which was generally high throughout the early Paleogene but further increased toward the EECO (Pearson and Palmer, 2000; Fletcher et al.,
2008; Lowenstein and Demicco, 2006; Smith et al., 2010; Hyland and Sheldon, 2013). However, as evident from the large range in $\delta^{13} \mathrm{C}$ across early Paleogene stable-isotope records, major changes in the storage and release of organic carbon must have additionally contributed to variability in atmospheric $p \mathrm{CO}_{2}$ and ocean DIC concentrations (Shackleton, 1986; Kurtz et al., 2003; Komar et al., 2013). When longterm increases in $p \mathrm{CO}_{2}$, perhaps in conjunction with orbital forcing, pushed temperatures across some threshold, such as the limit of sea-ice formation (Lunt et al., 2011), rapid inputs of ${ }^{13} \mathrm{C}$-depleted organic carbon from the shallow geosphere served as a positive feedback to abrupt warming (Dickens et al., 1995; Bowen et al., 2006; DeConto et al., 2012). 
Our new $\delta^{13} \mathrm{C}$ records do not directly address the above questions and narrative concerning early Paleogene carbon cycling. However, they do highlight two general and related problems when such a discussion includes the EECO. First, surface temperatures appear to stay high across an extended time interval when the $\delta^{13} \mathrm{C}$ of benthic foraminifer (Fig. 1) and bulk carbonate (Fig. 9) increase. Second, numerous brief CIEs mark this global long-term rise in $\delta^{13} \mathrm{C}$. Whether the aforementioned views need modification or reconsideration (Kirtland-Turner et al., 2014) is an issue as yet unresolved and one that depends on how long-term and short-term $\delta^{13} \mathrm{C}$ changes relate across the entire early Paleogene.

The overall offset between bulk carbonate $\delta^{13} \mathrm{C}$ values at Possagno and Site 577 may hint at an important constraint to any model of early Paleogene carbon cycling. Throughout the early Eocene, $\delta^{13} \mathrm{C}$ values at Site 577 exceed those at Possagno by nominally $0.8 \%$ (Fig. 9). This probably does reflect recrystallization or lithification because similar offsets appear across numerous records independent of postdepositional history but dependent on location (Schmitz et al., 1996; Cramer et al., 2003; Slotnick et al., 2012, 2015a; Agnini et al., 2016). In general, absolute values of bulk carbonate $\delta^{13} \mathrm{C}$ records increase from the North Atlantic and western Tethys (low), through the South Atlantic and eastern Tethys and the Indian Ocean, to the Pacific (high), although, significantly, with a latitudinal component to this signature.

\subsection{Stable oxygen isotope stratigraphy across the EECO}

Bulk carbonate $\delta^{18} \mathrm{O}$ values for Holocene sediment across the eastern equatorial Pacific relate to average temperatures in the mixed layer (Shackleton and Hall, 1995; Reghellin et al., 2015). Indeed, values are close to those predicted from water chemistry $\left(\delta^{18} \mathrm{O}_{\mathrm{w}}\right)$ and equilibrium calculations for calcite precipitation (e.g., Bemis et al., 1998) if vital effects in the dominant nannoplankton increase $\delta^{18} \mathrm{O}$ by nominally $1 \%$ (Reghellin et al., 2015).

Site 577 was located at about $15^{\circ} \mathrm{N}$ latitude in the eastern Pacific during the early Paleogene. Given that sediment of this age remains "nannofossil ooze" (Shipboard Scientific Party, 1985), one might predict past mixed layer temperatures from the $\delta^{18} \mathrm{O}$ values with three assumptions: early Paleogene $\delta^{18} \mathrm{O}_{\mathrm{w}}$ was $1.2 \%$ less than that in the present day to account for an ice-free world; local $\delta^{18} \mathrm{O}_{\mathrm{w}}$ was equal to average seawater, similar to modern chemistry at this offEquator location (LeGrande and Schmidt, 2006); and, Paleogene nannoplankton also fractionated $\delta^{18} \mathrm{O}$ by $1.0 \%$. With commonly used equations that relate the $\delta^{18} \mathrm{O}$ of calcite to temperature (Bemis et al., 1998), these numbers render temperatures of between 16 and $21^{\circ} \mathrm{C}$ for the data at Site 577 . Such temperatures seem too cold by at least $10^{\circ} \mathrm{C}$, given other proxy data and modeling studies (e.g., Pearson et al., 2007; Huber and Caballero, 2011; Hollis et al., 2012; Pross et al., 2012; Inglis et al., 2015). At low latitudes, bottom wa- ters are always much colder than surface waters. Even during the EECO, deep waters probably did not exceed $12^{\circ} \mathrm{C}(\mathrm{Za}-$ chos et al., 2008). The calculated temperatures likely indicate partial recrystallization of bulk carbonate near the seafloor. Examinations of calcareous nannofossils in Paleogene sediment at Site 577 show extensive calcite overgrowths (Shipboard Scientific Party, 1985; Backman, 1986). Relatively low $\delta^{18} \mathrm{O}$ values mark the $\mathrm{H}-1$ and $\mathrm{K} / \mathrm{X}$ events, as well as the main phase of the EECO (Fig. 5). Both observations support the idea that the bulk carbonate $\delta^{18} \mathrm{O}$ at Site 577 represents the combination of a primary surface water $\delta^{18} \mathrm{O}$ signal and a secondary shallow pore water $\delta^{18} \mathrm{O}$ signal.

Lithification should further impact bulk carbonate $\delta^{18} \mathrm{O}$ records (Marshall, 1992; Schrag et al., 1995; Frank et al., 1999). Because this process occurs well below the seafloor, where temperatures approach or exceed those of surface water, the $\delta^{18} \mathrm{O}$ values of pelagic marls and limestones should be significantly depleted in ${ }^{18} \mathrm{O}$ relative to partially recrystallized nannofossil ooze. This explains the nominal $2 \%$ offset in average $\delta^{18} \mathrm{O}$ between correlative strata at Possagno and at Site 577. While temperature calculations using the $\delta^{18} \mathrm{O}$ record at Possagno render reasonable surface water values for a midlatitude location in the early Paleogene $\left(26-31^{\circ} \mathrm{C}\right.$, using the aforementioned approach), any interpretation of these terms more than likely reflects happenstance. The fact that planktic foraminifera are completely recrystallized and totally filled with calcite at Possagno supports this inference.

One might suggest, at least for the Possagno section, that meteoric water might also have impacted the $\delta^{18} \mathrm{O}$ record. This is because rainwater generally has a $\delta^{18} \mathrm{O}$ composition less than that of seawater. However, samples were collected from fresh quarry cuts at Possagno in 2002-2003.

As observed at Site 577 , however, horizons of lower $\delta^{18} \mathrm{O}$ at Possagno may represent times of relative warmth in surface water. This includes the broad interval between 16 and $22.5 \mathrm{~m}$, which marks the main phase of the EECO, as well as many of the brief CIEs, at least one that clearly represents the PETM (Fig. 4). That is, despite obvious overprinting of the original $\delta^{18} \mathrm{O}$ signal, early to early middle Eocene climate variations appear manifest in the data.

\subsection{The EECO and planktic foraminiferal abundances}

Bulk carbonate $\delta^{13} \mathrm{C}$ records, especially in conjunction with other stratigraphic markers, provide a powerful means to correlate early Paleogene sequences from widely separated locations (Fig. 9). They also allow for the placement of planktic foraminiferal assemblage changes into a broader context.

The most striking change in planktic foraminiferal assemblages occurred near the start of the EECO. Over a fairly short time interval and at multiple widespread locations, the relative abundance of Acarinina increased significantly, whereas the relative abundance of Morozovella decreased significantly. This switch, best defined by the decline in $\mathrm{Mo}$ rozovella, happened just before the condensed interval at 
Possagno (Fig. 6), just above the J event at Site 577 (Fig. 7, Table S4) and during the J event at Site 1051 (Fig. 8). At the Farra section, cropping out in the same geological setting of Possagno at $50 \mathrm{~km}$ NE of the Carcoselle quarry, it also appears to have occurred close to the J event (Fig. 10). Indeed, the maximum turnover in relative abundances may have been coincident with the $\mathrm{J}$ event at all locations. Importantly, the relative abundance of subbotinids only changed marginally during this time.

The Morozovella decline across the start of the EECO did not rebound afterward. At Possagno, at Site 1051 and at Site 577, it was coupled with the gradual disappearances of several species, including M. aequa, M. gracilis, M. lensiformis, M. marginodentata and M. subbotinae. Furthermore, the loss of Morozovella was not counterbalanced by the appearance of the Morozovelloides genus, which shared the same ecological preferences with Morozovella. This latter genus appeared in C21r, near the Ypresian-Lutetian boundary, and well after the EECO (Pearson et al., 2006; Aze et al., 2011), including at Possagno (Luciani and Giusberti, 2014; Fig. 6). Though Morozovelloides were morphologically similar to Morozovella, they probably evolved from Acarinina (Pearson et al., 2006; Aze et al., 2011; Fig. 1).

At Possagno, higher abundances of Acarinina also correlate with pronounced negative $\delta^{13} \mathrm{C}$ perturbations before and after the EECO (Fig. 6). This includes the $\mathrm{H}-1$ event, as well as several unlabeled CIEs during C22n, C21r and C21n. Such increases in the relative abundances of Acarinina have been described for the PETM interval at the nearby Forada section (Luciani et al., 2007) and for the K/X event at the proximal Farra section (Agnini et al., 2009). Unlike for the main switch near the $\mathrm{J}$ event, however, these changes are transient, so that relative abundances in planktic foraminiferal genera are similar before and after the short-term CIEs.

\subsection{The impact of dissolution}

Carbonate dissolution at or near the seafloor presents a potential explanation for observed changes in foraminiferal assemblages. Some studies of latest Paleocene to initial Eocene age sediments, including laboratory experiments, suggest a general ordering of dissolution according to genus, with Acarinina more resistant than Morozovella and the latter more resistant than subbotinids (Petrizzo et al., 2008; Nguyen et al., 2009, 2011).

Carbonate solubility horizons that impact calcite preservation and dissolution on the seafloor (i.e., the carbonate compensation depth (CCD) and lysocline) also shoaled considerably during various intervals of the early Eocene. The three most prominent hyperthermals that occurred before the main phase of the EECO (PETM, H-1, K/X) were clearly marked by pronounced carbonate dissolution at multiple locations (Zachos et al., 2005; Agnini et al., 2009; Stap et al., 2009; Leon-Rodriguez and Dickens, 2010). A multi-millionyear interval characterized by a relatively shallow CCD also

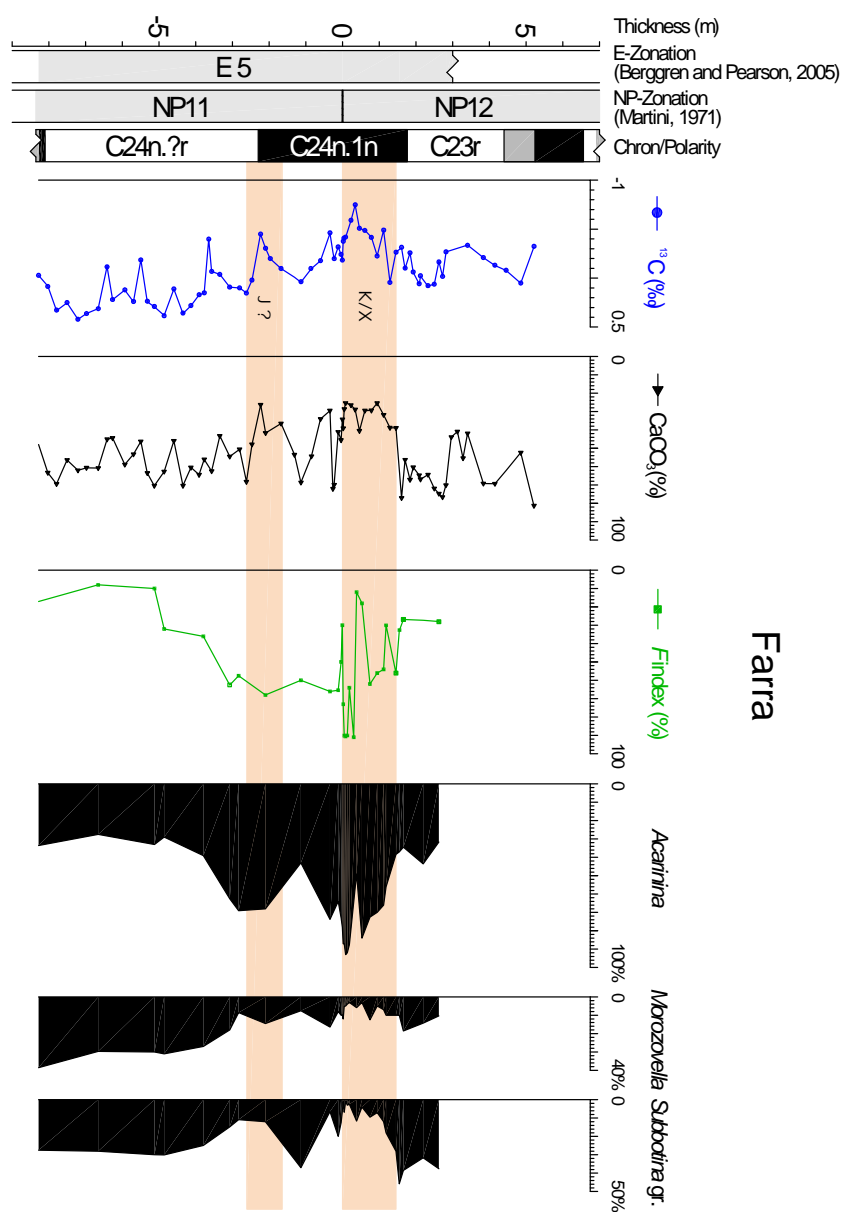

Figure 10. Records of magnetostratigraphy, bulk sediment $\delta^{13} \mathrm{C}$, $\mathrm{CaCO}_{3}$ content, $F$-index and abundance patterns for primary planktic foraminiferal taxa at the Farra section, which crops out $50 \mathrm{~km}$ NE of Possagno. All data are from Agnini et al. (2009). Note that the switch in abundance between Morozovella and Acarinina occurs close to the J event.

follows the K/X event (Leon-Rodriguez and Dickens, 2010; Pälike et al., 2012; Slotnick et al., 2015b).

Should changes in carbonate preservation primarily drive the observed planktic foraminiferal assemblages, it follows that the dominance of Acarinina during the EECO and multiple CIEs could represent a taphonomic artifact. Limited support for this idea comes from our records of fragmentation ( $F$-index). In general, intervals with relatively high abundances of Acarinina (and low $\delta^{13} \mathrm{C}$ ) correspond to intervals of fairly high fragmentation at Possagno and at Site 1051 (Figs. 6, 8). This may suggest carbonate dissolution because this process breaks planktic foraminifera into fragments (Berger, 1967; Hancock and Dickens, 2005).

Carbonate dissolution can cause the coarse fraction of bulk sediment to decrease (Berger et al., 1982; Broecker et al., 1999; Hancock and Dickens, 2005). This happens because whole planktic foraminiferal tests typically exceed 
$63 \mu \mathrm{m}$, whereas the resulting fragments often do not exceed $63 \mu \mathrm{m}$. The decrease in CF values at the start of the EECO at Possagno (Fig. 6) may therefore further indicate loss of foraminiferal tests. However, relatively low CF values continue to the top of the section, independent of changes in the $F$-index. The CF record parallels the trend in Morozovella abundance and thus might also suggest a loss of larger $\mathrm{Mo}$ rozovella rather than carbonate dissolution.

The cause of the long-term rise in carbonate dissolution horizons remains perplexing but may relate to increased inputs of ${ }^{13} \mathrm{C}$-depleted carbon into the ocean and atmosphere (Leon-Rodriguez and Dickens, 2010; Komar et al., 2013). Should the Morozovella decline and amplified $F$-index at the Possagno section mostly represent dissolution, it would imply considerable shoaling of these horizons in the western Tethys, given the inferred deposition in middle to lower bathyal setting. As with open-ocean sites (Slotnick et al., 2015b), further studies on the Eocene lysocline and CCD are needed from Tethyan locations. One idea is that remineralization of organic matter intensified within the water column, driven by augmented microbial metabolic rates at elevated temperatures during the EECO; this may have decreased $\mathrm{pH}$ at intermediate water column depths (Brown et al., 2004; Olivarez Lyle and Lyle, 2006; O'Connor et al., 2009; John et al., 2013, 2014).

Despite evidence of carbonate dissolution, this process probably only amplified primary changes in planktic foraminiferal assemblages. The most critical observation is the similarity of the abundance records for major planktic foraminiferal genera throughout the early Eocene at multiple locations (Figs. 6-8). This includes the section at Site 1051, where carbonate appears only marginally modified by dissolution according to the $F$-index values (Fig. 7). Subbotinid abundance also remains fairly high throughout the early Eocene. One explanation is that, in contrast to the results from laboratory experiments (Nguyen et al., 2009, 2011), subbotinids are more resistant to dissolution than $\mathrm{Mo}$ rozovella (Boersma and Premoli Silva, 1983; Berggren and Norris, 1997), at least once the EECO has transpired. In the proximal middle-upper Eocene section at Alano, Luciani et al. (2010) documented a dominance of subbotinids within intervals of high fragmentation ( $F$-index) and enhanced carbonate dissolution. The degree of dissolution across planktic foraminiferal assemblages may have varied through the early Paleogene, as distinct species within each genus may respond differently (Nguyen et al., 2011). So far, data on dissolution susceptibility for different species and genera are limited for early and early middle Eocene times (Petrizzo et al., 2008).

There is also recent work from the Terche section (ca. $28 \mathrm{~km}$ NE of Possagno) to consider. This section is located in the same geological setting as Possagno, but across the $\mathrm{H}-1, \mathrm{H}-2$ and $\mathrm{I} 1$ events, there are very low $F$-index values and marked increases in Acarinina coupled with significant decreases in subbotinids (D'Onofrio et al., 2014). Therefore, although the Possagno record may be partially altered by dis- solution, an increase in warm water Acarinina concomitant with a decrease in subbotinids seems to be a robust finding during early Paleogene warming events in Tethyan settings.

\subsection{A record of mixed water change}

The switch in abundance between Morozovella and Acarinina at the start of the EECO supports a hypothesis whereby environmental change resulted in a geographically widespread overturn of planktic foraminiferal genera. During the PETM and K/X events, Acarinina became dominant over Morozovella in a number of Tethyan successions. This has been interpreted as signifying enhanced eutrophication of surface waters near continental margins (Arenillas et al., 1999; Molina et al., 1999; Ernst et al., 2006; Guasti and Speijer, 2007; Luciani et al., 2007; Agnini et al., 2009), an idea consistent with evidence for elevated (albeit more seasonal) riverine discharge during these hyperthermals (Schmitz and Pujalte, 2007; Giusberti et al., 2007; Schulte et al., 2011; Slotnick et al., 2012; Pujalte et al., 2015). Increased nutrient availability may also have occurred at Possagno during the early part of the EECO, given the relatively high concentration of radiolarians, which may reflect eutrophication (Hallock, 1987).

However, the fact that the major switch at the start of the EECO can be found at Sites 1051 (western Atlantic) and Site 577 (central Pacific) suggests that local variations in oceanographic conditions, such as riverine discharge, were not the primary causal mechanism. Rather, the switch must be a consequence of globally significant modifications related to the EECO, most likely sustained high temperatures, elevated $p \mathrm{CO}_{2}$ or both. Given model predictions for our Earth in the coming millennia (IPCC, 2014), indirect effects could also have contributed, especially including increased ocean stratification and decreased $\mathrm{pH}$.

An explanation for the shift may lie in habitat differences across planktic foraminiferal genera. Although both Morozovella and Acarinina likely had photosymbionts, Morozovella may have occupied a shallower surface habitat than the latter genus as indicated by minor variations in their stable-isotope compositions (Boersma et al., 1987; Pearson et al., 1993, 2001).

One important consideration for any interpretation is the evolution of new species that progressively appear during the post-EECO interval. In good agreement with studies of lower Paleogene sediment from other low-latitude locations (Pearson et al., 2006), thermocline dwellers such as subbotinids and parasubbotinids seem to proliferate at Possagno (Luciani and Giusberti, 2014). These include Subbotina corpulenta, S. eocaena, S. hagni, S. senni, S. yeguanesis, Parasubbotina griffinae and $P$. pseudowilsoni. The appearance of the radially chambered Parasubbotina eoclava, considered to be the precursor of the truly clavate chambered Clavigerinella (Coxall et al., 2003; Pearson and Coxall, 2014), also occurs at $19.8 \mathrm{~m}$ and in the core of the EECO (Luciani and 


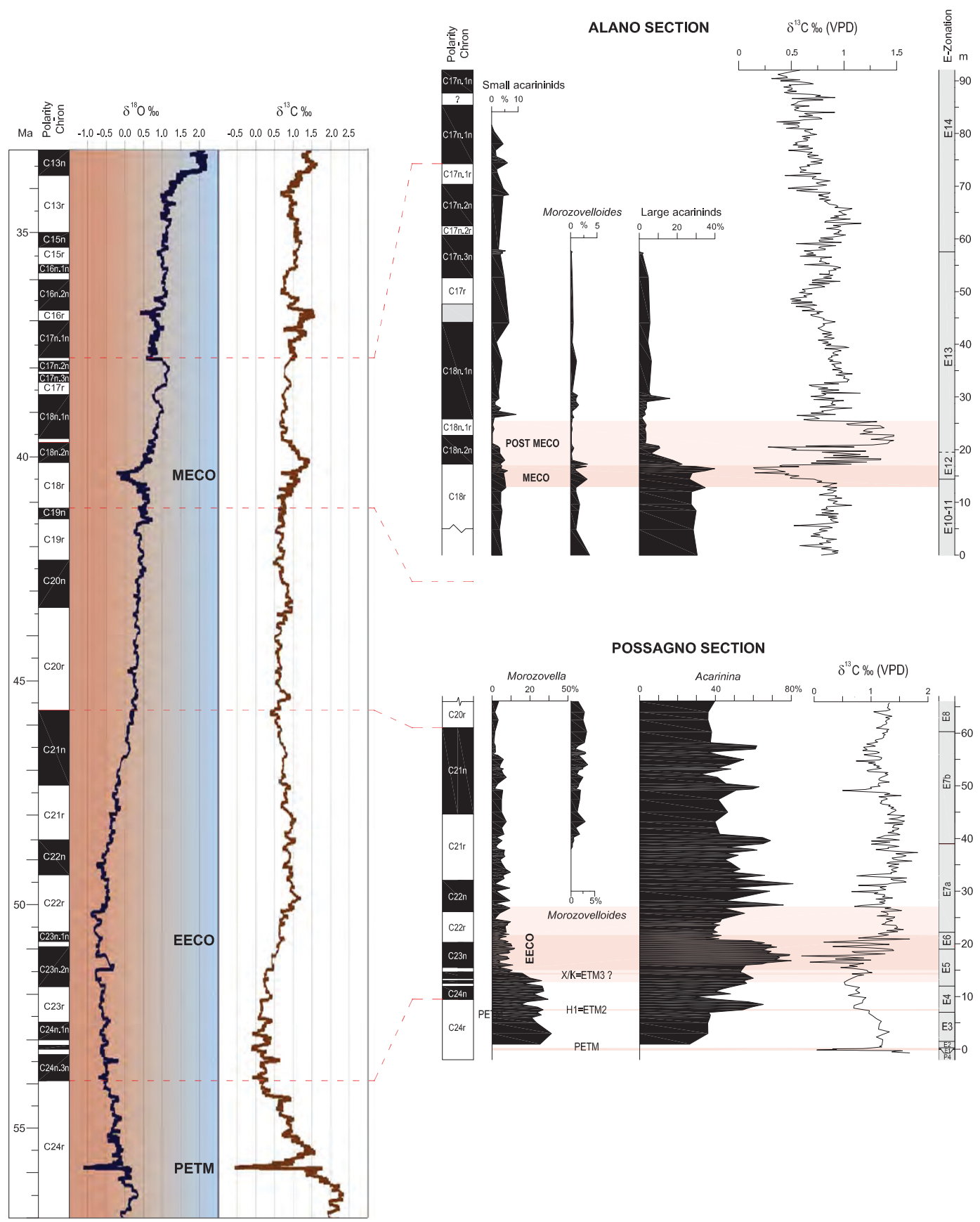

Figure 11. Records of Morozovella and large Acarinina (> 200 micron) in the western Tethyan setting from the Possagno section (this paper) and the Alano section (Luciani et al., 2010), plotted with generalized $\delta^{13} \mathrm{C}$ and $\delta^{18} \mathrm{O}$ curves for benthic foraminiferal on the GTS2012 (as summarized by Vandenberghe et al. (2012); slightly modified). These records suggest that the long-lasting EECO and MECO intervals of anomalous warmth mark two main steps in the decline in Morozovella, Morozovelloides and Acarinina. The planktic foraminiferal biozones follow those presented by Wade et al. (2011), as partly modified by Luciani and Giusberti (2014).

Giusberti, 2014). Clavigerinella is the ancestor of the genus Hantkenina, which successfully inhabited the subsurface and surface waters during the middle through late Eocene (Coxall et al., 2000).
A second consideration is the change in planktic foraminiferal assemblages during the Middle Eocene Climate Optimum (MECO), another interval of anomalous and prolonged warmth at ca. $40 \mathrm{Ma}$ (Bohaty et al., 2009). At Alano (Fig. 11) and other locations (Luciani et al., 2010; 
Edgar et al., 2012), the MECO involved the reduction in the abundance and test size of large Acarinina and Morozovelloides. This has been attributed to "bleaching", i.e., the loss of photosymbionts, resulting from global warming (Edgar et al., 2012), although related factors, such as a decrease in $\mathrm{pH}$, a decrease in nutrient availability or changes in salinity, may have been involved (Douglas, 2003; Wade et al., 2008). The symbiotic relationship with algae is considered an important strategy adopted by muricate planktic foraminifera during the early Paleogene (Norris, 1996; Quillévéré et al., 2001). Considering the importance of this relationship in extant species (Bé, 1982; Bé et al., 1982; Hemleben et al., 1989), the loss of photosymbionts may represent a crucial mechanism to explain the relatively rapid decline in foraminifera utilizing this strategy, including Morozovella at the start of the EECO.

Available data suggest that the protracted conditions of extreme warmth and high $p \mathrm{CO}_{2}$ during the EECO were the key elements inducing a permanent impact on planktic foraminiferal evolution and the decline in Morozovella. Even the PETM, the most pronounced hyperthermal, did not adversely affect the genus Morozovella permanently. While excursion taxa appeared, Morozovella seem to have increased in abundance in open-ocean settings (Kelly et al., 1996, 1998, 2002; Lu and Keller, 1995; Petrizzo, 2007); only in some continental margin settings did a transient decrease in abundance occur (Luciani et al., 2007).

\subsection{Post-EECO changes at Possagno}

Several small CIEs appear in the $\delta^{13} \mathrm{C}$ record at Possagno during polarity chrons C22n, C21r and C21n. Some of these post-EECO excursions coincide with planktic foraminiferal assemblage changes similar to those recorded in lower strata. Specifically, there are marked increases in Acarinina (Fig. 6). These "post-EECO" CIEs are concomitant with $\delta^{18} \mathrm{O}$ excursions and coupled to distinct modifications in the planktic foraminiferal assemblages comparable to those recorded across known hyperthermals in Tethyan settings (Luciani et al., 2007; Agnini et al., 2009; D'Onofrio et al., 2014). Additional hyperthermals, although of less intensity and magnitude, may extend through the entirety of the early and middle Eocene, as suggested previously (Sexton et al., 2006, 2011; Kirtland-Turner et al., 2014). Whether these imply different forcing and feedback mechanisms compared to the PETM remains an open question.

\section{Summary and conclusions}

The symbiont-bearing planktic foraminiferal genera Morozovella and Acarinina were among the most important calcifiers of the early Paleogene tropical and subtropical oceans. However, a remarkable and permanent switch in the relative abundance of these genera happened in the early Eocene, an evolutionary change accompanied by species reduction in Morozovella and species diversification of Acarinina. We show here that this switch probably coincided with a carbon isotope excursion presently coined J. Although the Early Eocene Climatic Optimum (EECO), a multi-million-year interval of extreme Earth surface warmth, lacks an accepted definition, we propose that the EECO is best defined as the duration of time between the J event and the base of $D$. sublodoensis (about 53 to $49 \mathrm{Ma}$ on the $2012 \mathrm{GTS}$ ).

Our conclusion that the planktic foraminiferal switch coincides with the start of the EECO derives from the generation of new records and collation of old records concerning bulk sediment stable isotopes and planktic foraminiferal abundances at three sections. These sections span a wide longitude range of the low-latitude Paleogene world: the Possagno section from the western Tethys, DSDP Site 577 from the central Pacific Ocean and ODP Site 1051 from the western Atlantic Ocean. Importantly, these locations have robust calcareous nannofossils and polarity chron age markers, although the stratigraphy required amendment at Sites 577 and 1051.

An overarching problem is that global carbon cycling was probably very dynamic during the EECO. The interval appears to have been characterized not only by numerous CIEs but also by a major switch in the timing and magnitude of these perturbations. Furthermore, there was a rapid shoaling of carbonate dissolution horizons in the middle of the EECO. A key finding of our study is that the major switch in planktic foraminiferal assemblages happened at the start of the EECO. Significant, though ephemeral, modifications in planktic foraminiferal assemblages coincide with numerous short-term CIEs, before, during and after the EECO. Often, there are marked increases in the relative abundance of Acarinina, similar to what happened permanently across the start of the EECO.

Although we show for the first time that the critical turnover in planktic foraminifera clearly coincided with the start of the EECO, the exact cause for the switch (a.k.a. the decline in Morozovella) remains elusive. Possible causes are manifold and may include temperature effects on photosymbiont-bearing planktic foraminifera, changes in ocean chemistry or even interaction with other microplankton groups such as radiolarians, diatoms or dinoflagellates that represented possible competitors in the use of symbionts or as symbiont providers. For some reason, a critical threshold was surpassed at the start the EECO, and this induced an unfavorable habitat for continued Morozovella diversification and proliferation but a favorable habitat for the genus Acarinina. 
Appendix A: Taxonomic list of planktic foraminiferal species cited in text and figures

Globanomalina australiformis (Jenkins, 1965)

Morozovella aequa (Cushman and Renz, 1942)

Morozovella gracilis (Bolli, 1957)

Morozovella lensiformis (Subbotina, 1953),

Morozovella marginodentata (Subbotina, 1953)

Morozovella subbotinae (Morozova, 1939)

Parasubbotina eoclava Coxall, Huber and Pearson, 2003

Parasubbotina griffinae (Blow, 1979)

Parasubbotina pseudowilsoni Olsson and Pearson, 2006

Subbotina corpulenta (Subbotina, 1953)

Subbotina eocaena (Gümbel, 1868)

Subbotina hagni (Gohrbandt, 1967)

Subbotina senni (Beckmann, 1953)

Subbotina yeguanesis (Weinzierl and Applin, 1929)

Planoglobanomalina pseudoalgeriana Olsson and

Hemleben, 2006
Appendix B: Taxonomic list of calcareous nannofossil taxa cited in text and figures

Discoaster diastypus Bramlette and Sullivan, 1961

Discoaster lodoensis Bramlette and Sullivan, 1961

Discoaster sublodoensis Bramlette and Sullivan, 1961

Fasciculithus Bramlette and Sullivan, 1961

Fasciculithus tympaniformis Hay and Mohler in

Hay et al., 1967

Sphenolithus radians Deflandre in Grassé, 1952

Toweius Hay and Mohler, 1967

Tribrachiatus contortus (Stradner, 1958); Bukry, 1972

Tribrachiatus orthostylus (Bramlette and Riedel, 1954);

Shamrai, 1963 


\section{The Supplement related to this article is available online at doi:10.5194/cp-12-981-2016-supplement.}

Acknowledgements. Initial and primary funding for this research was provided by MIUR/PRIN COFIN 2010-2011, coordinated by D. Rio. V. Luciani was financially supported by FAR from Ferrara University, and L. Giusberti and E. Fornaciari received financial support from Padova University (Progetto di Ateneo GIUSPRAT10). J. Backman acknowledges support from the Swedish Research Council. G. Dickens received support from the Swedish Research Council and the US NSF (grant NSF-FESD-OCE-1338842). We are grateful to Domenico Rio, who initiated the research on the "Paleogene Veneto", for fruitful discussion. Members of the "Possagno net", Simone Galeotti, Dennis Kent and Giovanni Muttoni, who sampled the Possagno section in 2002-2003, are gratefully acknowledged. We warmly acknowledge the Cementi Rossi s.p.a. and Silvano Da Roit for collaborations during sampling at the Carcoselle Quarry (Possagno, TV). This research used samples and data provided by the Ocean Drilling Program (ODP). ODP is sponsored by the US National Science Foundation (NSF) and participating countries under the management of the Joint Oceanographic Institution (JOI) Inc. We especially thank staff at the ODP Bremen Core Repository. Finally, we are grateful to the reviewers, P. Pearson, R. Speijer and B. Wade and to the editor A. Sluijs, who gave very detailed and constructive reviews that improved the paper significantly.

Edited by: A. Sluijs

\section{References}

Abels, H. A., Clyde, W. C., Gingerich, P. D., Hilgen, F. J., Fricke, H. C., Bowen, G. J., and Lourens, L. J.: Terrestrial carbon isotope excursions and biotic change during Palaeogene hyperthermals, Nat. Geosci., 5, 326-329, doi:10.1038/ngeo1427, 2012.

Agnini, C., Muttoni, G., Kent, D. V., and Rio, D.: Eocene biostratigraphy and magnetic stratigraphy from Possagno, Italy: the calcareous nannofossils response to climate variability, Earth Planet. Sc. Lett., 241, 815-830, 2006.

Agnini, C., Macrì, P., Backman, J., Brinkhuis, H., Fornaciari, E., Giusberti, L., Luciani, V., Rio, D., Sluijs, A., and Speranza, F.: An early Eocene carbon cycle perturbation at $\sim 52.5 \mathrm{Ma}$ in the Southern Alps: chronology and biotic response, Paleoceanography, 24, PA2209, doi:10.1029/2008PA001649, 2009.

Agnini, C., Fornaciari, E., Raffi, I., Catanzariti, R., Pälike, H., Backman, J., and Rio, D.: Biozonation and biochronology of Paleogene calcareous nannofossils from low to middle latitudes, Newsl. Strat., 47, 131-181, 2014.

Agnini, C., Spofforth, D. J. A., Dickens, G. R., Rio, D., Pälike, H., Backman, J., Muttoni, G., and Dallanave, E.: Stable isotope and calcareous nannofossil assemblage record of the late Paleocene and early Eocene (Cicogna section), Clim. Past, 12, 883-909, doi:10.5194/cp-12-883-2016, 2016.

Anderson, T. F. and Cole, S. A.: The stable isotope geochemistry of marine coccoliths: a preliminary comparison with planktonic foraminifera, J. Foramin. Res., 5, 188-192, 1975.
Arenillas, I., Molina, E., and Schmitz, B.: Planktic foraminiferal and $\delta^{13} \mathrm{C}$ isotopic changes across the Paleocene/Eocene boundary at Possagno (Italy), Int. J. Earth Sci., 88, 352-364, 1999.

Arthur, M. A., Dean, W. E., Bottjer, D., and Schole, P. A.: Rhythmic bedding in Mesozoic-Cenozoic pelagic carbonate sequences: the primary and diagenetic origin of Milankovitch like cycles, in: Milankovitch and Climate, edited by: Berger, A., Imbrie, J., Hays, J., Kucla, G., and Satzman, B., 191-222, D. Reidel Publ. Company, Dordrecht, Holland, 1984.

Aze, T., Ezard, T. H. G., Purvis, A., Coxall, H. K., Stewart, D. R. M, Wade, B. S., and Pearson, P. N.: A phylogeny of Cenozoic macroperforate planktonic foraminifera from fossil data, Biol. Rev., 86, 900-927, doi:10.1111/j.1469185X.2011.00178.x, 2011.

Backman, J.: Late Paleocene to middle Eocene calcareous nannofossil biochronology from the Shatsky Rise, Walvis Ridge and Italy, Palaeogeogr. Palaeocl., 57, 43-59, 1986.

Bé, A. W. H.: Biology of planktonic foraminifera, in: Foraminifera: notes for a short course, Broadhead T., Stud. Geol., 6, Univ. Knoxville, Tenn., 51-92, 1982.

Bé, A. W. H., John, W. M., and Stanley, M. H.: Progressive dissolution and ultrastructural breakdown of planktic foraminifera, Cushman Foundation for Foraminiferal Research Special Publication, 13, 27-55, 1975.

Bé, A. W. H., Spero, H. J., and Anderson, O. R.: Effects of symbiont elimination and reinfection on the life processes of the planktonic foraminifer Globigerinoides sacculifer, Mar. Biol., 70, 7386,1982

Bemis, B. E., Spero, H. J., Bijma, J., and Lea, D. W.: Reevaluation of the oxygen isotopic composition of planktonic foraminifera: Experimental results and revised paleotemperature equations, Paleoceanography, 13, 150-160, 1998.

Berger, W. H.: Foraminiferal ooze: Solution at depth, Science, 156, 383-385, 1967.

Berger, W. H.: Planktonic foraminifera - selective solution and lysocline, Mar. Geol., 8, 111-138, 1970.

Berger, W. H., Bonneau, M.-C., and Parker, F. L.: Foraminifera on the deep-sea floor: lysocline and dissolution rate, Oceanol. Acta 5, 249-258, 1982.

Berggren, W. A. and Norris, R. D.: Biostratigraphy, phylogeny and systematics of Paleocene trochospiral planktic foraminifera, Micropaleontology, 43 (Suppl. 1), 1-116, 1997.

Berggren, W. A. and Pearson, P. N.: A revised tropical to subtropical Paleogene planktic foraminiferal zonation, J. Foramin. Res., 35 279-298, 2005.

Berggren, W. A., Kent, D. V., Swisher III, C. C., and Aubry, M.-P.: A revised Cenozoic geochronology and chronostratigraphy, in: Geochronology, time scales and global stratigraphic correlation, edited by: Berggren, W. A, Kent, D. V., Aubry, M.-P., and Hardenbol, J., SEPM Special Publication, 54, 129-212, 1995.

Bijl, P. K., Schouten, S., Sluijs, A., Reichart, G.-J., Zachos, J. C., and Brinkhuis, H.: Early Paleogene temperature evolution of the southwest Pacific Ocean. Nature, 461, 776-779, doi:10.1038/nature08399, 2009.

Bijl, P. K., Bendle, J. A., Bohaty, S. M., Pross, J., Schouten, S., Tauxe, L., Stickley, C. E., McKay R. M., Röhl, U., Olney, M., Sluijs, A., Escutia Dotti, C., Brinkhuis, H., and Expedition 318 Scientists: Eocene cooling linked to early flow across the Tas- 
manian Gateway, P. Natl. Acad. Sci. USA, 110, 9645-9650, doi:10.1073/pnas.1220872110, 2013.

Bleil, U.: The magnetostratigraphy of northwest Pacific sediments, Deep Sea Drilling Project Leg 86, Initial Rep. Deep Sea, 86, 441458, 1985.

Boersma, A. and Premoli Silva, I.: Paleocene planktonic foraminiferal biogeography and the paleoceanography of the Atlantic-Ocean, Micropaleontology, 29, 355-381, 1983.

Boersma, A., Premoli Silva, I., and Shackleton, N.: Atlantic Eocene planktonic foraminiferal biogeography and stable isotopic paleoceanography, Paleoceanography, 2, 287-331, 1987.

Bohaty, S. M., Zachos, J. C., Florindo, F., and Delaney, M. L.: Coupled greenhouse warming and deep-sea acidification in the middle Eocene, Paleoceanography, 24, PA2207, doi:10.1029/2008PA001676, 2009.

Bolli, H. M.: Monografia micropaleontologica sul Paleocene e sull'Eocene di Possagno, Provincia di Treviso, Italia, Mémoires Suisses de Paléontologie, 97, 222 pp., 1975.

Borre, M. and Fabricus, I. L.: Chemical and mechanical processes during burial diagenesis of chalk: an interpretation based on specific surface data of deep-sea sediments, Sedimentology, 45, 755-769, 1998.

Bosellini, A.: Dynamics of Tethyan carbonate platform, in: Controls on Carbonate Platform and Basin Platform, edited by: Crevello, P. D., Wilson, J. L., Sarg, J. F., and Read, J. F., SEPM Spec. Publ., 44, 3-13, 1989.

Bowen, G. J., Bralower, T. J., Delaney, M. R., Dickens, G. R., Kelly, D. C., Koch, P. L., Kump, L. R., Meng, J., Sloan, L. C., Thomas, E., Wing, S. L., and Zachos, J. C.: Eocene Hyperthermal Event Offers Insight Into Greenhouse Warming, EOS, 87, 165-169, doi:10.1029/2006EO170002, 2006.

Braga G.: L'assetto tettonico dei dintorni di Possagno (Trevigiano occidentale), Rendiconti dell'Accademia Nazionale dei Lincei, 8/48, 451-455, 1970.

Bramlette, M. N. and Riedel, W. R.: Stratigraphic value of discoasters and some other microfossils related to recent coccolithophores, J. Paleontol., 28, 385-403, 1954.

Broecker, W. S., Clark, E., McCorkle D. C., Peng, T.-H., Hajadas, I., and Bonani, G.: Evidence of a reduction in the carbonate ion content of the deep see during the course of the Holocene, Paleoceanography, 14, 744-752, 1999.

Brown, J. H., Gillooly, J. F., Allen, A. P., Savage, V. M., and West, G. B.: Toward a metabolic theory of ecology, Ecology, 85, 17711789, 2004.

Cita, M. B.: Stratigrafia della Sezione di Possagno, in: Monografia Micropaleontologica sul Paleocene e l'Eocene di Possagno, edited by: Bolli, H. M., Provincia di Treviso, Italia, Schweiz, Palaeontol. Abhandl., 97, 9-33, 1975.

Clyde, W. C., Gingerich, P. D., Wing, S. L., Röhl, U., Westerhold, T., Bowen, G., Johnson, K., Baczynski, A. A., Diefendorf, A., McInerney, F., Schnurrenberger, D., Noren, A., Brady, K., and the BBCP Science Team: Bighorn Basin Coring Project (BBCP): a continental perspective on early Paleogene hyperthermals, Sci. Dril., 16, 21-31, doi:10.5194/sd-16-21-2013, 2013.

Coccioni, R., Bancalà, G., Catanzariti, R., Fornaciari, E., Frontalini, F., Giusberti, L., Jovane, L., Luciani, V., Savian, J., and Sprovieri, M.: An integrated stratigraphic record of the Palaeocene-lower Eocene at Gubbio (Italy): new insights into the early Palaeogene hyperthermals and carbon isotope excursions, Terra Nova, 24, 380-386, 2012.

Coxall, H. K., Pearson, P. N., Shackleton, N. J., and Hall, M. A.: Hantkeninid depth adaptation: An evolving life strategy in a changing ocean, Geology, 28, 87-90, doi:10.1130/00917613(2000)28<87:HDAAEL>2.0.CO;2, 2000.

Coxall, H. K., Huber, B. T., and Pearson, P. N.: Origin and morphology of the Eocene planktic foraminifera Hantkenina, J. Foramin. Res., 33, 237-261, 2003.

Cramer, B. S., Wright, J. D., Kent, D. V., and Aubry, M.-P.: Orbital climate forcing of $\delta^{13} \mathrm{C}$ excursions in the late Paleoceneearly Eocene (chrons C24n-C25n), Paleoceanography, 18, 1097, doi:10.1029/2003PA000909, 2003.

Cramer, B. S., Toggweiler, J. R., Wright, M. E., Katz, J. D., and Miller, K. G.: Ocean overturning since the Late Cretaceous: Inferences from a new benthic foraminiferal isotope compilation, Paleoceanography, 24, PA4216, doi:10.1029/2008PA001683, 2009.

Crouch, E. M., Heilmann-Clausen, C., Brinkhuis, H., Morgans, H. E. G., Rogers, K. M., Egger, H., and Schmitz, B.: Global dinoflagellate event associated with the late Paleocene thermal maximum, Geology, 29, 315-318, 2001.

Dallanave, E., Agnini, C., Bachtadse, V., Muttoni, G., Crampton J. S., Strong, C. P., Hines, B. H., Hollis, C. J., and Slotnick, B. S.: Early to middle Eocene magneto-biochronology of the southwest Pacific Ocean and climate influence on sedimentation: Insights from the Mead Stream section, New Zealand, Geol. Soc. Am. Bull., 127, 643-660, 2015.

DeConto, R. M., Galeotti, S., Pagani, M., Tracy, D., Schaefer, K., Zhang, T., Pollard, D., and Beerling, D. J.: Past extreme warming events linked to massive carbon re-lease from thawing permafrost, Nature, 484, 87-92, doi:10.1038/nature10929, 2012.

Demicco, R. V.: Modeling seafloor-spreading rates through time, Geology, 32, 485-488, 2004.

Dickens, G. R.: Methane oxidation during the Late Palaeocene Thermal Maximum, B. Soc. Geol. Fr., 171, 37-49, 2000.

Dickens, G. R.: Down the Rabbit Hole: toward appropriate discussion of methane release from gas hydrate systems during the Paleocene-Eocene thermal maximum and other past hyperthermal events, Clim. Past, 7, 831-846, doi:10.5194/cp-7-831-2011, 2011.

Dickens, G. R. and Backman J.: Core alignment and composite depth scale for the lower Paleogene through uppermost Cretaceous interval at Deep Sea Drilling Project Site 577, Newsl. Stratigr., 46, 47-68, 2013.

Dickens, G. R., O’Neil, J. R., Rea, D. K., and Owen, R. M.: Dissociation of oceanic methane hydrate as a cause of the carbon isotope excursion at the end of the Paleocene, Paleoceanography, 10, 965-971, doi:10.1029/95PA02087, 1995.

Dickens, G. R., Castillo, M. M., and Walker, J. C. G.: A blast of gas in the latest Paleocene: simulating first-order effects of massive dissociation of oceanic methane hydrate, Geology, 25, 259-262, 1997.

D’Onofrio, R., Luciani, V., Giusberti, L., Fornaciari, E., and Sprovieri, M.: Tethyan planktic foraminiferal record of the early Eocene hyperthermal events ETM2, H2 and I1 (Terche section, northeastern Italy), Rendiconti Online della Società Geologica Italiana, 31, 66-67, doi:10.3301/ROL.2014.48, 2014. 
Douglas, A. E.: Coral bleaching - how and why?, Marine Pollut. Bull., 46 385-392, doi:10.1016/S0025-326X(03)00037-7, 2003.

Dunkley Jones, T., Lunt, D. J., Schmidt, D. N., Ridgwell, A., Sluijs, A., Valdez, P. J., and Maslin, M. A.: Climate model and proxy data constraints on ocean warming across the Paleocene-Eocene Thermal Maximum, Earth Sci. Rev., 125, 123-145, 2013.

Edgar, K. M., Bohaty, S. M., Gibbs, S. J., Sexton, P. F., Norris, R. D., and Wilson, P. A.: Symbiont "bleaching" in planktic foraminifera during the Middle Eocene Climatic Optimum, Geology, 41, 1518, doi:10.1130/G33388.1, 2012.

Ernst, S. R., Guasti, E., Dupuis, C., and Speijer, R. P.: Environmental perturbation in the southern Tethys across the Paleocene/Eocene boundary (Dababiya, Egypt): foraminiferal and clay mineral records, Mar. Micropaleontol., 60, 89-111, 2006.

Ezard, T. H. G., Aze, T., Pearson, P. N., and Purvis, A: Interplay between changing climate and species' ecology drives macroevolutionary dynamics, Science, 332, 349-351, 2011.

Falkowski, P. G., Katz, M. E., Milligan, A. J., Fennel, K., Cramer, B. S., Aubry, M. P., Berner, R. A., Novacek, M. J., and Zapol, W. M.: Mammals evolved, radiated, and grew in size as the concentration of oxygen in Earth's atmosphere increased during the past 100 million years, Science, 309, 2202-2204, 2005.

Figueirido, B., Janis, C. M., Pérez-Claros, J. A., De Renzi, M., and Palmqvist, P.: Cenozoic climate change influences mammalian evolutionary dynamics, P. Natl. Acad. Sci. USA, 109, 722-727, 2012.

Fletcher, B. J., Brentnall, S. J., Anderson, C. W., Berner, R. A., and Beerling, D. J.: Atmospheric carbon dioxide linked with Mesozoic and early Cenozoic climate change, Nat. Geosci., 1, 43-48, 2008.

Fornaciari, E., Giusberti, L., Luciani, V., Tateo, F., Agnini, C., Backman, J., Oddone, M., and Rio, D.: An expanded CretaceousTertiary transition in a pelagic setting of the Southern Alps (central-western Tethys), Palaeogeogr. Palaeocl., 255, 98-131, 2007.

Fraass, A. J., Kelly, D. K., and Peters, S. E.: Macroevolutionary history of the planktic foraminifera, Annu. Rev. Earth Pl. Sc., 43, 139-66, doi:10.1146/annurev-earth-060614-105059, 2015.

Frank, T. D., Arthur, M. A., and Dean, W. E.: Diagenesis of Lower Cretaceous pelagic carbonates, North Atlantic: paleoceanographic signals obscured, J. Foramin. Res., 29, 340-351, 1999.

Galeotti, S., Krishnan, S., Pagani, M., Lanci, L., Gaudio, A., Zachos, J. C., Monechi, S., Morelli, G., and Lourens, L. J.: Orbital chronology of early Eocene hyperthermals from the Contessa Road section, central Italy, Earth Planet. Sc. Lett., 290, 192-200, doi:10.1016/j.epsl.2009.12.021, 2010.

Gingerich, P. D.: Rates of evolution on the time scale of the evolutionary process, Genetica, 112-113, 127-144, 2001.

Gingerich, P. D.: Mammalian response to climate change at the Paleocene-Eocene boundary: Polecat Bench record in the northern Bighorn Basin, Wyoming, Geol. Soc. Am. Spec. Pap., 369, 463-478, 2003.

Giusberti, L., Rio, D., Agnini, C., Backman, J., Fornaciari, E., Tateo, E., and Oddone, M.: Mode and tempo of the PaleoceneEocene thermal maximum in an expanded section from the Venetian pre-Alps, Geol. Soc. Am. Bull., 119, 391-412, 2007.
Guasti, E. and Speijer, R. P.: The Paleocene-Eocene thermal maximum in Egypt and Jordan: an overview of the planktic foraminiferal record, Geol. Soc. Spec. Pap., 424, 53-67, 2007.

Hallock, P.: Fluctuations in the trophic resource continuum: a factor in global diversity cycles?, Paleoceanography, 2, 457-471, 1987.

Hancock, H. J. L. and Dickens, G. R.: Carbonate dissolution episodes in Paleocene and Eocene sediment, Shatsky Rise, westcentral Pacific, Proc. Ocean Drill. Progr., Sci. Results, 198, 24 pp., doi:10.2973/odp.proc.sr.198.116.2005, 2005.

Hemleben, C., Spindler, M., and Anderson, O. R. (Eds.).: Modern planktonic foraminifera, Springer-Verlag, New York, ISBN-13: 9780387968155, 1-363, 1989.

Hilgen, F. J., Abels, H. A., Kuiper, K. F., Lourens, L. J., and Wolthers, M.: Towards a stable astronomical time scale for the Paleocene: aligning Shatsky Rise with the Zumaia - Walvis Ridge ODP Site 1262 composite, Newsl. Stratigr., 48, 91-110, doi:10.1127/nos/2014/0054, 2015.

Hollis, C. J., Taylor, K. W. R., Handley, L., Pancost, R. D., Huber, M., Creech, J. B., Hines, B. R., Crouch, E. M., Morgans, H. E. G., Crampton, J. S., Gibbs, S., Pearson, P. N., and Zachos, J. C.: Early Paleogene temperature history of the Southwest Pacific Ocean: Reconciling proxies and models, Earth Planet. Sc. Lett., 349-350, 53-66, doi:10.1016/j.epsl.2012.06.024, 2012.

Huber, M. and Caballero, R.: The early Eocene equable climate problem revisited, Clim. Past, 7, 603-633, doi:10.5194/cp-7603-2011, 2011.

Hyland, E. G and Sheldon, N. D.: Coupled CO2-climate response during the Early Eocene Climatic Optimum, Palaeogeogr. Palaeocl., 369, 125-135, 2013.

Hyland, E. G., Sheldon, N. D., and Fan, M.: Terrestrial paleoenvironmental reconstructions indicate transient peak warming during the early Eocene climatic optimum, Geol. Soc. Am. Bull., 125, 1338-1348, 2013.

IPCC, 2014: Climate Change 2014: Synthesis Report, Contribution of Working Groups I, II and III to the Fifth Assessment Report of the Intergovernmental Panel on Climate Change, edited by: Core Writing Team, Pachauri, R. K., and Meyer, L. A., IPCC, Geneva, Switzerland, 151 pp., 2014.

Inglis, G. N., Farnsworth, A., Lunt, D., Foster, G. L., Hollis, C. J., Pagani, M., Jardine, P. E., Pearson, P. N., Markwick, P., Galsworthy, A. M. J., Raynham, L., Taylor, K. W. R., and Pancost, R. D.: Descent toward the icehouse: Eocene sea surface cooling inferred from GDGT distributions, Paleoceanography, 30, 1001020, doi:10.1002/2014PA002723, 2015.

Ito, G. and Clift, P. D.: Subsidence and growth of Pacific Cretaceous plateaus, Earth Plant. Sc. Lett., 161, 85-100, 1998.

John, E. H., Pearson, P. N., Coxall, H. K., Birch, H., Wade, B. S., and Foster, G. L.: Warm ocean processes and carbon cycling in the Eocene, Philos. T. R. Soc., A, 371, 20130099, doi:10.1098/rsta.2013.0099, 2013.

John, E. H., Wilson, J. D., Pearson, P. N., and Ridgwell, A.: Temperature-dependent remineralization and carbon cycling in the warm Eocene oceans, Palaeogeogr. Palaeocl., 413, 158-166, 2014.

Kelly, D. C., Bralower, T. J., Zachos, J. C., Premoli Silva, I., and Thomas, E.: Rapid diversification of planktonic foraminifera in the tropical Pacific (ODP Site 865) during the late Paleocene thermal maximum, Geology, 24, 423-426, 1996. 
Kelly, D. C., Bralower, T. J., and Zachos, J. C.: Evolutionary consequences of the latest Paleocene thermal maximum for tropical planktonic foraminifera, Palaeogeogr., Palaeoclimatol., Palaeoecol., 141, 139-161, 1998.

Kelly, D. C.: Response of Antartic (ODP) planktonic foraminifera to the Paleocene-Eocene Thermal Maximum: faunal evidence for ocean/climate change, Paleoceanography, 17, 1071, doi:10.1029/2002PA000761, 2002.

Kennett, J. P. and Stott, L. D.: Abrupt deep-sea warming, palaeoceanographic changes and benthic extinctions at the end of the Palaeocene, Nature, 353, 225-229, 1991.

Kirtland-Turner, S., Sexton, P. F., Charled, C. D., and Norris, R. D.: Persistence of carbon release events through the peak of early Eocene global warmth, Nat. Geosci., 7, 748-751, doi:10.1038/NGEO2240, 2014.

Komar, N., Zeebe, R. E., and Dickens, G. R.: Understanding long-term carbon cycle trends: the late Paleocene through the early Eocene, Paleoceanography, 28, 650-662, doi:10.1002/palo.20060, 2013.

Kroenke, L. W., Berger, W. H., Janecek, T. R., Backman, J., Bassinot, F., Corfield, R. M., Delaney, M. L., Hagen, R., Jansen, E., Krissek, L. A., Lange C., Leckie R. M., Lykke Lind, I., Lyle, M. W., Mahoney, J. J., Marsters, J. C., Mayer, L., Mosher, D. C., Musgrave, R., Prentice, M. L., Resig, J. M., Schmidt, H., Stax, R., Storey, M., Takahashi, K., Takayama, T., Tarduno, J. A., Wilkens, R. H., Wu, G., and Barbu, E. M.: Ontong Java Plateau, Leg 130: synopsis of major drilling results, Proceedings of the Ocean Drilling Program, Initial Reports, 130, 497-537, 1991.

Kurtz, A. C., Kump, L. R., Arthur, M. A., Zachos, J. C., and Paytan, A.: Early Cenozoic decoupling of the global carbon and sulfur cycles, Paleoceanography, 18, 1090, doi:10.1029/2003PA000908, 2003.

Lauretano, V., Littler, K., Polling, M., Zachos, J. C., and Lourens, L. J.: Frequency, magnitude and character of hyperthermal events at the onset of the Early Eocene Climatic Optimum, Clim. Past, 11, 1313-1324, doi:10.5194/cp-11-1313-2015, 2015.

Lee, C. T., Shen, B., Slotnick, B. S., Liao, K., Dickens, G. R., Yokoyama, Y., Lenardic, A., Dasgupta, R., Jellinek, M., Lackey, J. S., Schneider, T., and Tice, M. M.: Continental arc-island arc fluctuations, growth of crustal carbonates, and long-term climate change, Geosphere, 9, 21-36, 2013.

LeGrande, A. N. and Schmidt, G. A.: Global gridded data set of the oxygen isotopic composition in seawater, Geophys. Res. Lett., 33, L12604, doi:10.1029/2006GL026011, 2006.

Leon-Rodriguez, L. and Dickens, G. R.: Constraints on ocean acidification associated with rapid and massive carbon injections: The early Paleogene record at ocean drilling program site 1215 , equatorial Pacific Ocean, Palaeogeogr. Palaeocl., 298, 409-420, doi:10.1016/j.palaeo.2010.10.029, 2010.

Lirer, F.: A new technique for retrieving calcareous microfossils from lithified lime deposits, Micropaleontol., 46, 365-369, 2000.

Littler, K., Röhl, U., Westerhold, T., and Zachos, J. C.: A highresolution benthic stable-isotope for the South Atlantic: implications for orbital-scale changes in Late Paleocene-early Eocene climate and carbon cycling, Earth Planet. Sc. Lett., 401, 18-30, doi:10.1016/j.eps1.2014.05.054, 2014.

Lourens, L. J., Sluijs, A., Kroon, D., Zachos, J. C., Thomas, E., Röhl, U., Bowles, J., and Raffi, I.: Astronomical pacing of late
Palaeocene to early Eocene global warming events, Nature, 7045, 1083-1087, 2005.

Lowenstein, T. K. and Demicco R. V.: Elevated Eocene atmospheric $\mathrm{CO}_{2}$ and its subsequent decline, Science, 313, 1928, doi:10.1126/science.1129555, 2006.

Lu, G.: Paleocene-Eocene transitional events in the ocean: Faunal and isotopic analyses of planktic foraminifera, $\mathrm{PhD}$ Thesis, Princeton University, Princeton, 1-284, 1995.

Lu, G. and Keller, G.: Planktic foraminiferal faunal turnovers in the subtropical Pacific during the late Paleocene to early Eocene, J. Foramin. Res., 25, 97-116, 1995.

Lu, G., Keller, G., and Pardo, A.: Stability and change in Tethyan planktic foraminifera across the Paleocene-Eocene transition, Mar. Micropaleontol., 35, 203-233, 1998.

Luciani, V., Giusberti, L., Agnini, C., Backman, J., Fornaciari, E., and Rio., D.: The Paleocene-Eocene Thermal Maximum as recorded by Tethyan planktonic foraminifera in the Forada section (northern Italy), Mar. Micropaleontol., 64, 189-214, 2007.

Luciani, V., Giusberti, L., Agnini, C., Fornaciari, E., Rio, D., Spofforth, D. J. A., and Pälike, H.: Ecological and evolutionary response of Tethyan planktonic foraminifera to the middle Eocene climatic optimum (MECO) from the Alano section (NE Italy), Palaeogeogr. Palaeocl., 292, 82-95, doi:10.1016/j.palaeo.2010.03.029, 2010.

Luciani, V. and Giusberti, L.: Reassessment of the early-middle Eocene planktic foraminiferal biomagnetochronology: new evidence from the Tethyan Possagno section (NE Italy) and Western North Atlantic Ocean ODP Site 1051, J. Foramin. Res., 44, 187-201, 2014.

Lunt, D. J., Ridgwell, A., Sluijs, A., Zachos, J., Hunter, S., and Haywood, A.: A model for orbital pacing of methane hydrate destabilization during the Palaeogene, Nat. Geosci., 4, 775-778, doi:10.1038/NGEO1266, 2011.

Marshall, J. D.: Climatic and oceanographic isotopic signals from the carbonate rock records and their preservation, Geol. Mag., 129, 143-160, 1992.

Martini, E.: Standard Tertiary and Quaternary calcareous nannoplankton zonation, in: Proceedings of the 2nd Planktonic Conference, edited by: Farinacci, A., Edizioni Tecnoscienza, Roma, vol. 2, 739-785, 1971.

Matter, A., Douglas, R. G., and Perch-Nielsen, K: Fossil preservation, geochemistry and diagenesis of pelagic carbonates from Shatsky Rise, northwest Pacific, Initial Rep. Deep Sea, 32, 891922, doi:10.2973/dsdp.proc.32.137.1975, 1975.

McInerney, F. A. and Wing, S. L.: The Paleocene-Eocene thermal maximum: a perturbation of carbon cycle, climate, and biosphere with implications for the future, Ann. Rev. Earth Planet. Sci., 39, 489-516, doi:10.1146/annurev-earth-040610-133431, 2011.

Mita, I.: Data Report: Early to late Eocene calcareous nannofossil assemblages of Sites 1051 and 1052, Blake Nose, Northwestern Atlantic Ocean, Proc. Ocean Drill. Progr., Sci. Results, 171B, 128,2001 .

Molina, E., Arenillas, I., and Pardo, A.: High resolution planktic foraminiferal biostratigraphy and correlation across the Palaeocene Palaeocene/Eocene boundary in the Tethys, B. Soc. Géol. Fr., 170, 521-530, 1999.

Monechi, L., Bleil, U., and Backman, J.: Magnetobiochronology of Late Cretaceous-Paleogene and late Cenozoic pelagic sedimentary sequences from the northwest Pacific, Deep Sea Drilling 
Project, Leg 86, Site 577, Proceedings of the Ocean Drilling Program 86, Initial Reports, Ocean Drilling Program, College Station, TX, doi:10.2973/dsdp.proc.86.137.1985, 1985.

Nguyen, T. M. P., Petrizzo, M.-R., and Speijer, R. P.: Experimental dissolution of a fossil foraminiferal assemblage (PaleoceneEocene Thermal Maximum, Dababiya, Egypt): implications for paleoenvironmental reconstructions, Mar. Micropaleontol., 73, 241-258, doi:10.1016/j.marmicro.2009.10.005, 2009.

Nguyen, T. M. P., Petrizzo, M.-R., Stassen, P., and Speijer, R. P.: Dissolution susceptibility of Paleocene-Eocene planktic foraminifera: Implications for palaeoceanographic reconstructions, Mar. Micropaleontol., 81, 1-21, 2011.

Nicolo, M. J., Dickens, G. R., Hollis, C. J., and Zachos, J. C.: Multiple early Eocene hyperthermals: their sedimentary expression on the New Zealand continental margin and in the deep sea, Geology, 35, 699-702, 2007.

Norris, R. D.: Biased extinction and evolutionary trends, Paleobiology, 17, 388-399, 1991.

Norris, R.: Symbiosis as an evolutionary innovation in the radiation of Paleocene planktic foraminifera, Paleobiology, 22, 461-480, 1996.

Norris, R. D., Kroon, D., and Klaus, A.: Proceedings of the Ocean Drilling Program, Initial Reports, Proc. Ocean Drill. Progr., Sci. Results, 171B, 1-749, 1998.

O'Connor, M., Piehler, M. F., Leech, D. M., Anton, A., and Bruno, J. F.: Warming and resource availability shift food web structure and metabolism, PLOS Biol., 7, 1-6, doi:10.1371/journal.pbio.1000178, 2009.

Ogg, J. G. and Bardot, L.: Aptian through Eocene magnetostratigraphic correlation of the Blake Nose Transect (Leg 171B), Florida continental margin, Proc. Ocean Drill. Progr., Sci. Results, 171B, 1-58, doi:10.2973/odp.proc.sr.171B.104.2001, 2001.

Okada, H. and Bukry, D.: Supplementary modification and introduction of code numbers to the low-latitude coccolith biostratigraphic zonation (Bukry, 1973, 1975), Mar. Micropaleontol., 5, 321-325, 1980.

Olivarez Lyle, A. and Lyle, M. W.: Missing organic carbon in Eocene marine sediments: Is metabolism the biological feedback that maintains end-member climates?, Paleoceanography, 21, PA2007, doi:10.1029/2005PA001230, 2006.

Oreshkina, T. V.: Evidence of late Paleocene - early Eocene hyperthermal events in biosiliceous sediments of Western Siberia and adjacent areas, Aust. J. Earth Sci., 105, 145-153, 2012.

Pälike, H., Lyle, M. W., Nishi, H., Raffi, I., Ridgwell, A., Gamage, K., Klaus, A., Acton, G., Anderson, L., Backman, J., Baldauf, J., Beltran, C., Bohaty S. M., Bown, P., Busch, W. Channell, J. E. T., Chun, C. O. J., Delaney, M., Dewangan, P., Dunkley Jones, T., Edgar, K. M., Evans, H., Fitch, P. L., Foster, G. L., Gussone, N., Hasegawa, H., Hathorne, E. C., Hayashi, H., Herrle, J. O., Holbourn, A., Hovan, S., Hyeong, K., Iijima, K., Ito, T., Kamikuri, S., Kimoto, K., Kuroda, J., Leon-Rodriguez, L., Malinverno, A., Moore, T. C., Brandon, H., Murphy, D. P., Nakamura, H., Ogane, K., Ohneiser, C. Richter, C., Robinson, R., Rohling, E. J., Romero, O., Sawada, K., Scher, H., Schneider, L., Sluijs, A., Takata, H., Tian, J., Tsujimoto, A., Wade, B. S., Westerhold, T., Wilkens, R., Williams, T., Wilson, P. A., Yamamoto, Y., Yamamoto, S., Yamazaki, T., and Zeebe, R. E.: Cenozoic record of the equatorial Pacific carbonate compensation depth, Nature, 488, 609-614, doi:10.1038/nature11360, 2012.

Pearson P. N. and Coxall, H. K.: Origin of the Eocene planktonic foraminifer Hantkenina by gradual evolution, Palaeontology, 57, 243-267, 2014.

Pearson, P. N. and Palmer, M. R.: Atmospheric carbon dioxide concentrations over the past 60 million years, Nature, 406, 695-699, doi:10.1038/35021000, 2000.

Pearson, P. N., Shackleton, N. J., and Hall, M. A.: Stable isotope paleoecology of middle Eocene planktonic foraminifera and multispecies isotope stratigraphy, DSDP Site 523, south Atlantic, J Foramin. Res., 23, 123-140, 1993.

Pearson, P. N., Ditchfield, P. W, Singano, J., Harcourt-Brown, K. G., Nicholas, C. J., Olsson, R. K, Shackleton, N. J., and Hall, M. A.: Warm tropical sea surface temperatures in the Late Cretaceous and Eocene epochs, Nature, 413, 481-487, doi:10.1038/35097000, 2001.

Pearson, P. N., Olsson, R. K., Huber, B. T., Hemleben, C., and Berggren, W. A. (Eds.): Atlas of Eocene planktonic foraminifera, Cushman Found, Foram. Res., Spec. Publ., 41, 1-514, 2006.

Pearson, P. N., Van Dongen, B. E., Nicholas, C. J., Pancost, R. D., Schouten, S., Singano, J. M., and Wade, B. S.: Stable warm tropical climate through the Eocene Epoch, Geology, 35, 211-214, 2007.

Petrizzo, M. R.: The onset of the Paleocene-Eocene Thermal Maximum (PETM) at Sites 1209 and 1210 (Shatsky Rise, Pacific Ocean) as recorded by planktonic foraminifera, Mar. Micropaleontol., 63, 187-200, 2007.

Petrizzo, M.-R., Leoni, G., Speijer, R. P., De Bernardi, B., and Felletti, F.: Dissolution susceptibility of some Paleogene planktonic foraminifera from ODP Site 1209 (Shatsky Rise, Pacific Ocean), J. Foramin. Res., 38, 357-371, 2008.

Pross, J., Contreras, L., Bijl, P. K., Greenwood, D. R., Bohaty, S. M., Schouten, S., Bendle J. A., Röhl, U., Tauxe, L., Raine, J. I., Claire, E., Huck, C. E., van de Flierdt, T., Stewart S. R. Jamieson, S. S. R., Stickley, C. E., van de Schootbrugge, B., Escutia, C., and Brinkhuis, H.: Persistent near-tropical warmth on the Antarctic continent during the early Eocene Epoch, Nature, 488, 73-77, doi:10.1038/nature11300, 2012.

Pujalte, V., Baceta, J. I., and Schmitz, B.: A massive input of coarsegrained siliciclastics in the Pyrenean Basin during the PETM: the missing ingredient in a coeval abrupt change in hydrological regime, Clim. Past, 11, 1653-1672, doi:10.5194/cp-11-16532015, 2015.

Quillévéré, F., Norris, R. D., Moussa, I., and Berggren, W. A.: Role of photosymbiosis and biogeography in the diversification of early Paleogene acarininids (planktonic foraminifera), Paleobiology, 27, 311-326, 2001.

Raffi, I. and De Bernardi, B.: Response of calcareous nannofossils to the Paleocene-Eocene Thermal Maximum: observations on composition, preservation and calcification in sediments from ODP Site 1263 (Walvis Ridge-SW Atlantic), Mar. Micropaleontol., 69, 119-138, 2008.

Raymo, M. E. and Ruddiman W. F.: Tectonic forcing of late Cenozoic climate, Nature, 359, 117-122, 1992.

Reghellin, D., Coxall, H. K., Dickens, G. R., and Backman, J.: Carbon and oxygen isotopes of bulk carbonate in sediment deposited beneath the eastern equatorial Pacific over 
the last 8 million years, Paleoceanography, 30, 1261-1286, doi:10.1002/2015PA002825, 2015.

Röhl, U., Westerhold, T., Monechi, S., Thomas, E., Zachos, J. C., and Donner, B.: The third and final early Eocene Thermal Maximum: characteristics, timing, and mechanisms of the " $X$ " event, Geol. Soc. Am. Abstr. Programs, 37, p. 264, 2005.

Scheibner, C. and Speijer, R. P.: Decline of coral reefs during late Paleocene to early Eocene global warming, eEarth, 3, 19-26, doi:10.5194/ee-3-19-2008, 2008.

Schlanger, S. O. and Douglas, R. G.: The pelagic ooze-chalklimestone transition and its implications for marine stratigraphy, in: Pelagic Sediments: on Land and under the Sea, edited by: Hsü, K. J. and Jenkyns, H. C., Sp. Publ. Int., 1, 117-148, 1974.

Schmidt, D. N., Thierstein, H. R., and Bollmann, J.: The evolutionary history of size variation of planktic foraminiferal assemblages in the Cenozoic, Palaeogeogr. Palaeocl., 212, 159-180, doi:10.1016/j.palaeo.2004.06.002, 2004.

Schmitz, B. and Pujalte, V.: Abrupt increase in seasonal extreme precipitation at the Paleocene-Eocene boundary, Geology, 35, 215-218, 2007.

Schneider, L. J. Bralower, T. J., and Kump, L. J.: Response of nannoplankton to early Eocene ocean destratification, Palaeogeogr. Palaeocl., 310, 152-162, 2011.

Scholle, P. A. and Arthur, M. A.: Carbon isotope fluctuations in Cretaceous pelagic limestones: potential stratigraphic and petroleum exploration tool, Am. Assoc. Petr. Geol. B., 64, 67-87, 1980.

Schulte, P., Scheibner, C., and Speijer, R.C.: Fluvial discharge and sea-level changes controlling black shale deposition during the Paleocene-Eocene Thermal Maximum in the Dababiya Quarry section, Egypt, Chem. Geol., 285, 167-183, doi:10.1016/j.chemgeo.2011.04.004, 2011.

Schrag, D. P., DePaolo, D. J., and Richter, F. M.: Reconstructing past sea surface temperatures: correcting for diagenesis of bulk marine carbonate, Geochim. Cosmochim. Ac., 59, 2265-2278, 1995.

Schmitz, B., Speijer, R. P., and Aubry M.-P.: Latest Paleocene benthic extinction event on the southern Tethyan shelf (Egypt): Foraminiferal stable isotopic $\left(\delta^{13} \mathrm{C}, \delta^{18} \mathrm{O}\right)$ records, Geology, 24, 347-350, 1996.

Self-Trail, J. M., Powars, D. S., Watkins, D. K., and Wandless, G. A.: Calcareous nannofossil assemblage changes across the Paleocene-Eocene Thermal Maximum: Evidence from a shelf setting, Mar. Micropaleontol., 92-93, 61-80, 2012.

Sexton, P. F., Wilson, P. A., and Norris, R. D.: Testing the Cenozoic multisite composite $\delta^{18} \mathrm{O}$ and $\delta^{13} \mathrm{C}$ curves: New monospecific Eocene records from a single locality, Demerara Rise (Ocean Drilling Program Leg 207), Paleoceanography, 21, PA2019, doi:10.1029/2005PA001253, 2006.

Sexton, P. F., Norris R. D., Wilson, P. A., Pälike, H., Westerhold, T., Röhl, U., Bolton, C. T., and Gibbs, S.: Eocene global warming events driven by ventilation of oceanic dissolved organic carbon, Nature, 471, 349-353, doi:10.1038/nature09826, 2011.

Shackleton, N. J.: Paleogene stable isotope events, Palaeogeogr. Palaeocl., 57, 91-102, 1986.

Shackleton, N. J. and Hall, M. A.: Carbon isotope data from Leg 74 sediments, Initial Rep. Deep Sea, 74, 613-619, 1984.

Shackleton, N. J. and Hall, M. A.: Stable isotope records in bulk sediments (Leg 138), Proc. Ocean Drill. Progr., Sci. Results, 138, 797-805, doi:10.2973/odp.proc.sr.171B.104.2001, 1995.
Shamrock, J. L., Watkins, D. K., and Johnston, K. W.: Eocene biogeochronology of ODP Leg 122 Hole 762C, Exmouth Plateau (northwest Australian Shelf), Stratigraphy, 9, 55-76, 2012.

Shipboard Scientific Party, 1985, Site 577: Initial Rep. Deep Sea, 86, edited by: Heath, G. R., Burckle, L. H., Heath, G. R., Burckle, L. H., D’Agostino, A. E., Bleil, U., Horai, K., Jacobi, R. D., Janecek, T. R., Koizumi, I., Krissek, L. A., Monechi, S., Lenotre, N., Morley, J. J., Schultheiss, P. J., Wright, A. A., and Turner, K. L., US Government Printing Office, Washington, 91137, doi:10.2973/dsdp.proc.86.104.1985, 1985.

Shipboard Scientific Party, 1998, Site 1051: Proceeding Ocean Drilling Program, Initial Reports, 171B, edited by: Norris, R. D., Kroon, D., Klaus, A., Norris, R. D., Kroon, D., Klaus, A., Alexander, I. T., Bardot, L. P., Barker, C. E., Bellier, J.-P., Blome, C. D., Clarke, L. J., Erbacher, J., Faul, K. L., Holmes, M., Huber, B. T., Katz, M. E., MacLeod, K. G., Marca, S., MartinezRuiz, F. C., Mita, I., Nakai, M., Ogg, J. G., Pak, D. K., Pletsch, T. K., Self-Trail, J. M., Shackleton, N. J., Smit, J., Ussler III, W., Watkins, D. K., Widmark, J., Wilson, P. A., Baez, L. A., and Kapitan-White, E., Ocean Drilling Program, College Station, TX, 171-239, doi:10.2973/odp.proc.ir.171b.105.1998, 1998.

Sims, P. A., Mann, D. G., and Medlin, L. K.: Evolution of the diatoms: insights from fossil, biological and molecular data, Phycologia, 45, 361-402, 2006.

Sinton, C. W. and Duncan R. A.: ${ }^{40} \mathrm{Ar}-{ }^{39} \mathrm{Ar}$ ages of lavas from the southeast Greenland margin, ODP Leg 152, and the Rockall Plateau, DSDP Leg 81, Ocean Drill. Progr., Sci. Res., 152, 387-402, doi:10.2973/odp.proc.sr.152.234.1998, 1998.

Slotnick, B. S., Dickens, G. R., Nicolo, M. J., Hollis, C. J., Crampton, J. S., Zachos, J. C., and Sluijs, A.: Large-amplitude variations in carbon cycling and terrestrial weathering during the latest Paleocene and earliest Eocene: The Record at Mead Stream, New Zealand, J. Geol., 120, 487-505, 2012.

Slotnick, B. S., Dickens, G. R., Hollis, C. J., Crampton, J. S., Percy Strong, C., and Zachos, J. C.: Extending lithologic and stable carbon isotope records at Mead Stream (New Zealand) through the middle Eocene, in: Dickens G.R., Luciani V. eds. Climatic and biotic events of the Paleogene 2014 CBEP 2014, Volume 31, Roma, Società Geologica Italiana, 201-202, 2014.

Slotnick, B. S., Dickens, G. R., Hollis, C. J., Crampton, J. S., Strong, P. S., and Phillips, A.: The onset of the Early Eocene Climatic Optimum at Branch Stream, Clarence River valley, New Zealand, New Zeal. J. Geol. Geop., 58, 1-19, doi:10.1080/00288306.2015.1063514, 2015a.

Slotnick, B. S., Lauretano, V., Backman, J., Dickens, G. R., Sluijs, A., and Lourens, L.: Early Paleogene variations in the calcite compensation depth: new constraints using old borehole sediments from across Ninetyeast Ridge, central Indian Ocean, Clim. Past, 11, 473-493, doi:10.5194/cp-11-473-2015, 2015b.

Sluijs, A. and Dickens, G. R.: Assessing offsets between the $\delta^{13} \mathrm{C}$ of sedimentary components and the global exogenic carbon pool across early Paleogene carbon cycle perturbations, Global Biogeochem. Cy., 26, GB4019, doi:10.1029/2011GB004094, 2012.

Sluijs, A., Schouten, S., Pagani, M., Woltering, M., Brinkhuis, H., Sinninghe Damsté, J. S., Dickens, G. R., Huber, M., Reichart, G., Stein, R., Matthiessen, J., Lourens, L. J., Pedentchouk, N., Backman, J., Moran, K., and the Expedition 302 Scientists: Subtropical Arctic Ocean temperatures during the 
Palaeocene/Eocene thermal maximum, Nature, 441, 610-613, doi:10.1038/nature04668, 2006.

Sluijs, A., Bowen, G. J., Brinkhuis, H., Lourens, L. J., and Thomas, E.: The Paleocene-Eocene thermal maximum super greenhouse: biotic and geochemical signatures, age models and mechanisms of global change, in: Deep-Time Perspectives on Climate Change, edited by: Williams, M., Haywood, A. M., Gregory, F. J., and Schmidt, D. N., Micropalaeont. Soc. Spec. Publ., Geological Society, London, 323-350, 2007.

Smith, R. Y., Greenwood, D. R., and Basinger, J. F.: Estimating paleoatmospheric $p \mathrm{CO}_{2}$ during the Early Eocene Climatic Optimum from stomatal frequency of Ginkgo, Okanagan Highlands, British Columbia, Canada, Palaeogeogr. Palaeocl., 293, 120 131,2010

Stap, L., Sluijs, A., Thomas, E., and Lourens L. J.: Patterns and magnitude of deep sea carbonate dissolution during Eocene Thermal Maximum 2 and H2, Walvis Ridge, southeastern Atlantic Ocean, Paleoceanography, 24, 1211, doi:10.1029/2008PA001655, 2009.

Thomas, E.: Biogeography of the late Paleocene benthic foraminiferal extinction, in: Late Paleocene-early Eocene climatic and biotic events in the marine and terrestrial Records, edited by: Aubry, M.-P., Lucas, S., and Berggren, W. A., Columbia University Press, New York, 214-243, 1998.

Thomas, E., Brinkhuis, H., Huber, M., and Röhl, U.: An ocean view of the early Cenozoic Greenhouse world, Oceanography, 19, 94 103, 2006.

Thunell R. C. and Honjo, S.: Calcite dissolution and the modification of planktonic foraminiferal assemblages, Mar. Micropaleontol., 6, 169-182, 1981 .

Vandenberghe, N., Hilgen, F. J., Speijer, R. P., Ogg, J. G., Gradstein, F. M., Hammer, O., Hollis, C. J., and Hooker, J. J.: The Paleogene Period, in: The Geologic Time Scale 2012, edited by: Gradstein, F., Ogg, J. G., Schmitz, M. D., and Ogg, G. M., 855921, Elsevier, Amsterdam, 2012.

Van Hinsbergen, D. J. J., de Groot, L. V., van Schaik, S. J., Spakman, W., Bijl, P. K., Sluijs, A., Langereis, C. G., and Brinkhuis, H.: A Paleolatitude Calculator for Paleoclimate Studies, PLoS ONE, 10, e0126946, doi:10.1371/journal.pone.0126946, 2015.

Vincent, E. and Berger, W. H: Planktonic foraminifera and their use in paleoccanography; in: The Sea, edited by: Emiliani, C., New York, 7, 1025-1119, 1981.

Vogt, P. R.: Global magmatic episodes: New evidence and implications for the steady state mid-oceanic ridge, Geology, 7, 93-98, 1979.

Wade, B. S.: Planktonic foraminiferal biostratigraphy and mechanisms in the extinction of Morozovella in the late Middle Eocene, Mar. Micropaleontol., 51, 23-38, 2004.

Wade, B. S., Al-Sabouni, N., Hemleben, C., and Kroon, D.: Symbiont bleaching in fossil planktonic foraminifera, Evol. Ecol., 22, 253-265, doi:10.1007/s10682-007-9176-6, 2008.
Wade, B. S., Pearson, P. N., Berggren, W. A., and Pälike, H.: Review and revision of Cenozoic tropical planktonic foraminiferal biostratigraphy and calibration to the geomagnetic polarity and astronomical time scale, Earth Sci. Rev., 104, 111-142, doi:10.1016/j.earscirev.2010.09.003, 2011.

Westerhold, T., Röhl, U., Frederichs, T., Bohaty, S. M., and Zachos, J. C.: Astronomical calibration of the geological timescale: closing the middle Eocene gap, Clim. Past, 11, 1181-1195, doi:10.5194/cp-11-1181-2015, 2015.

Wilf, P., Cúneo, R. N., Johnson, K. R., Hicks, J. F., Wing, S. L., and Obradovich, J. D.: High plant diversity in Eocene South America: evidence from Patagonia, Science, 300, 122-125, 2003.

Wing, S. L., Bown, T. M., and Obradovich, J. D.: Early Eocene biotic and climatic change in interior western North America, Geology, 19, 1189-1192, 1991.

Woodburne, M. O., Gunnell, G. F., and Stucky, R. K.: Climate directly influences Eocene mammal faunal dynamics in North America, P. Natl. Acad. Sci. USA, 106, 13399-13403, 2009.

Yamaguchi, T. and Norris R. D.: Deep-sea ostracode turnovers through the Paleocene-Eocene thermal maximum in DSDP Site 401, Bay of Biscay, North Atlantic, Mar. Micropaleontol., 86-87, 32-44, 2012.

Yapp, C. J.: $\mathrm{Fe}\left(\mathrm{CO}_{3}\right) \mathrm{OH}$ in goethite from a mid-latitude North American Oxisol: Estimate of atmospheric $\mathrm{CO}_{2}$ concentration in the early Eocene "climatic optimum", Geochim. Cosmochim. Ac., 68, 935-947, doi:10.1016/j.gca.2003.09.002, 2004.

Zachos, J. C., Pagani, M., Sloan, L., Thomas, E., and Billups, K.: Trends, rhythms, and aberrations in global climate $65 \mathrm{Ma}$ to Present, Science, 292, 686-693, 2001.

Zachos, J. C., Röhl, U., Schellenberg, S. A., Sluijs, A., Hodell, D. A., Kelly, D. C., Thomas, E., Nicolo, M., Raffi, I., Lourens, L. J., McCarren, H., and Kroon, D.: Rapid acidification of the ocean during the Paleocene-Eocene thermal maximum, Science, 308, 1611-1615, 2005.

Zachos, J. C., Dickens, G. R., and Zeebe, R. E.: An early Cenozoic perspective on greenhouse warming and carbon-cycle dynamics, Nature, 451, 279-283, 2008.

Zachos, J. C., McCarren, H., Murphy, B., Röhl, U., and Westerhold, T.: Tempo and scale of late Paleocene and early Eocene carbon isotope cycles: Implications for the origin of hyperthermals, Earth Planet. Sc. Lett., 299, 242-249, doi:10.1016/j.epsl.2010.09.004, 2010.

Zeebe, R. E., Zachos, J. C., and Dickens, G. R.: Carbon dioxide forcing alone insufficient to explain PalaeoceneEocene Thermal Maximum warming, Nat. Geosci., 2, 576-580, doi:10.1038/ngeo578, 2009.

Zonneveld, J. P., Gunnell, G. F., and Bartels, W. S.: Early Eocene fossil vertebrates from the southwestern Green River Basin, Lincoln and Uinta Counties, Wyoming, J. Vertebr. Paleontol., 20, 369-386, 2000. 